Article

\title{
Fostering Sustainable Urban-Rural Linkages through Local Food Supply: A Transnational Analysis of Collaborative Food Alliances
}

\author{
Potira Preiss ${ }^{1,2, *}$, Flávia Charão-Marques ${ }^{2}$ and Johannes S. C. Wiskerke ${ }^{1}$ (D) \\ 1 Rural Sociology Group, Wageningen University, Hollandseweg 1, $6706 \mathrm{KN}$ Wageningen, The Netherlands; \\ han.wiskerke@wur.nl \\ 2 Federal University of Rio Grande do Sul (UFRGS), Av. João Pessoa, 31-Porto Alegre, Brazil; \\ flavia.marques@ufrgs.br \\ * Correspondence: potira.preiss@ufrgs.br; Tel.: +55-51-9847-80892
}

Received: 25 May 2017; Accepted: 28 June 2017; Published: 2 July 2017

\begin{abstract}
The mainstream system of food supply has been heavily criticized in the last years due to its social and environmental impacts. Direct food purchasing schemes have emerged in recent decades as a form of supply that may be more ecologically sound and socially just, while allowing for a closer relationship between producers and consumers. The aim of this article is to show how a specific kind of direct supply, Collaborative Food Alliances, may help to foster sustainable urban-rural linkages. This paper presents, compares and discusses seven different cases, located in five different countries: Movimento de Integração Campo-Cidade (MICC) (Brazil), Canasta Comunitaria Utopía (Ecuador), GAS Testaccio Meticcio and Gasper (Italy), Grupo de Consumo Vera and Grupo de Consumo de Russafa (Spain), and De Groene Schuur at Zeist (The Netherlands). Analysis of the seven cases reveals that, through alliances between consumers and producers, solidarity and sustainable food supply are built. City dwellers benefit from such alliances by receiving organic products on a stable basis and at a fair price, while providing farmers with a stable income.
\end{abstract}

Keywords: producers and consumers alliances; local food supply; urban-rural linkages; sustainable food

\section{Introduction}

According to the United Nation's Food and Agricultural Organization (FAO) [1], facing the challenges of the 21st century - such as urbanization, population growth and climate change-makes it urgent to re-think the ways in which food provision is organized. According to the FAO "high-input, resource-intensive farming systems, which have caused massive deforestation, water scarcities, soil depletion and high levels of greenhouse gas emissions, cannot deliver sustainable food and agricultural production" [1]. The FAO therefore calls, amongst others, for developing systems of food provisioning that protect and enhance the natural resource base and that are more socially inclusive (for both farmers as well as consumers).

From a social perspective, capital-intensive and vertically integrated food systems have marginalized actors at both ends of the food supply chain. Small farmers have experienced increased levels of marginalization and vulnerability due to low remuneration and unequal bargaining power, making it harder to access markets [2]. On the consumer's side, two main problems have to be addressed. The first is the growing feeling of distrust in industrialized food due to an ongoing flow of food scares, such as "mad cow" disease, avian influenza, foot and mouth disease, and milk and meat adulterations. This has led consumers to question food quality and food safety [3]. The second problem concerns the alarming increase in diet-related ill-health problems caused by hunger, chronic malnutrition and obesity [4-6]. 
Another impact that affected both ends of the chain was the social and spatial distancing of markets, separating both the sites and the actors of production and consumption. Considering the increasing population in urban areas and the climate-induced disruptions to food supply, a challenge is posed to rethink food provisioning in more resilient and integrated ways. In this sense, it is necessary to develop strategies where urban centers and their surrounding (peri-urban and rural) areas can be encompassed in a foodscape perspective, in which the social, economic, and environmental effects of the food supply can be addressed in an innovative and integrated way.

In recent years different food supply schemes have emerged based upon a different rationale than high-input and resource-intensive farming and food supply systems. These schemes are characterized by processes of food re-localization both in terms of valorizing the territorial origin and identity of food as well as in reconnecting farmers and consumers [7]. These schemes have been described and analyzed in the international scientific literature using different conceptual frames. The most commonly used concepts are Local Food Systems (LFS), Alternative Food Networks (AFNs) [8], food movements [9], and, more recently, Civic Food Networks (CFN) [10]. Although these studies are very relevant and valuable in understanding the current resurgence of spatial and social proximity relations in food provisioning, the use of concepts like LFS, AFN and CFN tends to obfuscate the enormous diversity of practices, value relations and organizational forms that are covered by these concepts and that may range from specialized shops to farmers markets, home delivery systems, community-based urban gardening and "grow your own" initiatives. Furthermore, the concept of AFN has been heavily criticized for introducing a binary division between conventional and alternative, resulting in the assumption that both are homogeneous representations of oppositional food systems. Such binary thinking ignores the fact that both "the alternative" and "the conventional" may coexist in continuous and interrelated spaces, mutually influencing each other [11].

In this article we intend to go beyond the alternative-conventional binary and focus on a specific food scheme, that of direct food purchasing, in which consumers play an active role. Direct food purchasing is emerging and developing in different countries, albeit that organizational forms and identities may (slightly) differ between places. In the UK and north America the term Community Supported Agriculture (CSA) is frequently used; in France, they are known as Association Pour le Maintien d'une Agriculture Paysanne (AMAP, meaning Associations for the Maintenance of the Peasant Agriculture); in Italy, as Gruppi di Acquisto Solidari (GAS, Solidarity Purchasing Groups); in Spain, as Grupos de Consumo (Consumption Groups); in Ecuador, as Canastas Comunitarias (Community Baskets); and, in Brazil, as Grupos de Consumo Responsável (Responsible Consumption Groups). Scholars refer to the emergence of such schemes in different ways, Picolotto [12] argues that there is a connection with the consumer cooperatives from the early nineteenth century in Europe, inspired by the Utopian socialists such as Robert Owen. Star [13] on the other hand, believes that movements that emerged in Germany, Switzerland and Japan in the late 1960s, claiming for an "Agriculture with a face" are the inspirational basis for those experiences. Either way, it is clear that nowadays there is an impressive number of direct food purchasing schemes in different parts of the world: Lamine [14] argues that, in the United States and Canada, about 1400 CSAs were identified and, in France, about 15,000 families belong to AMAPs; in Italy, they are currently about 900 GAS [15]; Kirwan [16] estimates that more than 1400 households are involved with Canastas Comunitarias in Ecuador.

These schemes refer to forms of food supply in which organized groups establish direct relationships between consumers and producers for the provisioning of food products in order to create a relationship of loyalty and solidarity between those who produce and those who consume. In order to do this, specific agreements are established in ways that articulate different arrangements, organizational dynamics and even, innovative processes in the production and consumption. Based on a theoretical review and on a survey that focused on Brazilian experiences, Preiss and Charão-Marques (2015) already suggested that these specific arrangements form a particular type of food supply that differs from other forms of direct supply. Two aspects make the distinction, the alliance among producers and consumers and the collaborative working dynamic. We refer to 
it as Collaborative Food Alliances (CFA). Although CFAs exist and are emerging in many different countries, their characteristics and specificities may differ between countries and localities. Thus, in contrast to using umbrella concepts like LFS and AFN to address a wide variety of food provisioning practices and networks, CFA intends to be more specific by making clearer what kind of supply we are talking about, and by differentiating it from other forms of direct food supply such as farmers markets, home delivery systems, community-based urban gardening and "grow your own" initiatives. Besides the direct purchasing, it focuses on experiences where there is a collaboration between consumers and producers who both dedicate time, work and resources for the initiative to work In this sense, the alliance here refers not only to the alliance formed by consumers and producers, but also to the alliance between rural and urban, and people and food, in which there is a physical engagement to collaborate to accomplish desirable values and outcomes.

The aim of this article is to show how a specific kind of direct supply, Collaborative Food Alliances, may help to foster sustainable urban-rural linkages. The study elaborated in this article focuses on seven cases, located in five different countries, which are presented according to eleven heuristic analytical fields, highlighting similarities and differences in their origin, working dynamic, relationships and intended outcomes. Although they are heterogeneous, involving different circumstances, cultures and places, it is possible to identify elements in which they converge showing common elements and similarities. This introduction is followed by a section describing the methodology. After that we present the results case by case. The last part of the paper is dedicated to discuss the results and ends with the conclusions.

\section{Methodology}

The investigation is based on a qualitative approach that started with a review of European, North American and South American studies on direct and collaborative food purchasing. This review took into consideration academic research, grey literature, websites and social media. This was followed by field research using a multi-sited ethnographic approach. This approach was first proposed by Marcus [17] and has later been applied and developed by others, such as Falzon [18]; Vossoughi and Gutierrez [19] and Blanco, Arce and Fischer [20]. In essence, we followed the alliances among producers and consumers, searching for a deeper understanding of the circumstances that shape their practices and everyday experiences, understanding them as multidimensional and complex social phenomena. The field visits took place between January and December 2015 and the following methods were used for data collection: semi-structured interviews, participation, field notes, visual recordings and reviews of documents. The seven cases are located in five different cities and countries: Movimento de Integração Campo-Cidade (MICC) from São Paulo, Brazil; Canasta Comunitaria Utopía, from Riobamba, Ecuador; two Gruppi di Acquisto Solidari (GAS) from Rome, Italy, namely Testaccio Meticcio and G; two Grupos de Consumo from the Spanish city of Valencia, namely Grupo de Consumo Vera and Grupo de Consumo de Russafa; and De Groene Schuur from Zeist, The Netherlands (Figure 1).

The data presentation is inspired in the heuristic framework for exploring food projects proposed by Holloway and colleagues [21], which is suitable for addressing food production-consumption as inter-related fields, allowing to explore the circumstances, complexities, significances and multidimensional practices at play without simplistic categorizations such as alternative and conventional. Based on an analysis of over 100 food projects in the UK, the authors propose a series of analytical fields: (1) site of food production; (2) food production methods; (3) supply chain; (4) arena of exchange; (5) producer-consumer interaction; (6) motivations for participation; and (7) constitution of individual and group identities-as a methodological tool to describe projects in which food moves directly between producers and consumers, helping to understand how they are assembled and how they function in their specific local contexts. This proposal aims go beyond the problem of the conventional-alternative dualism, considering production and consumption as a relational set of practices. It also considers the importance of consumers as active participants in food provisioning as 
well as the material and embodied aspects of production and consumption that are arranged across a series of inter-related fields.

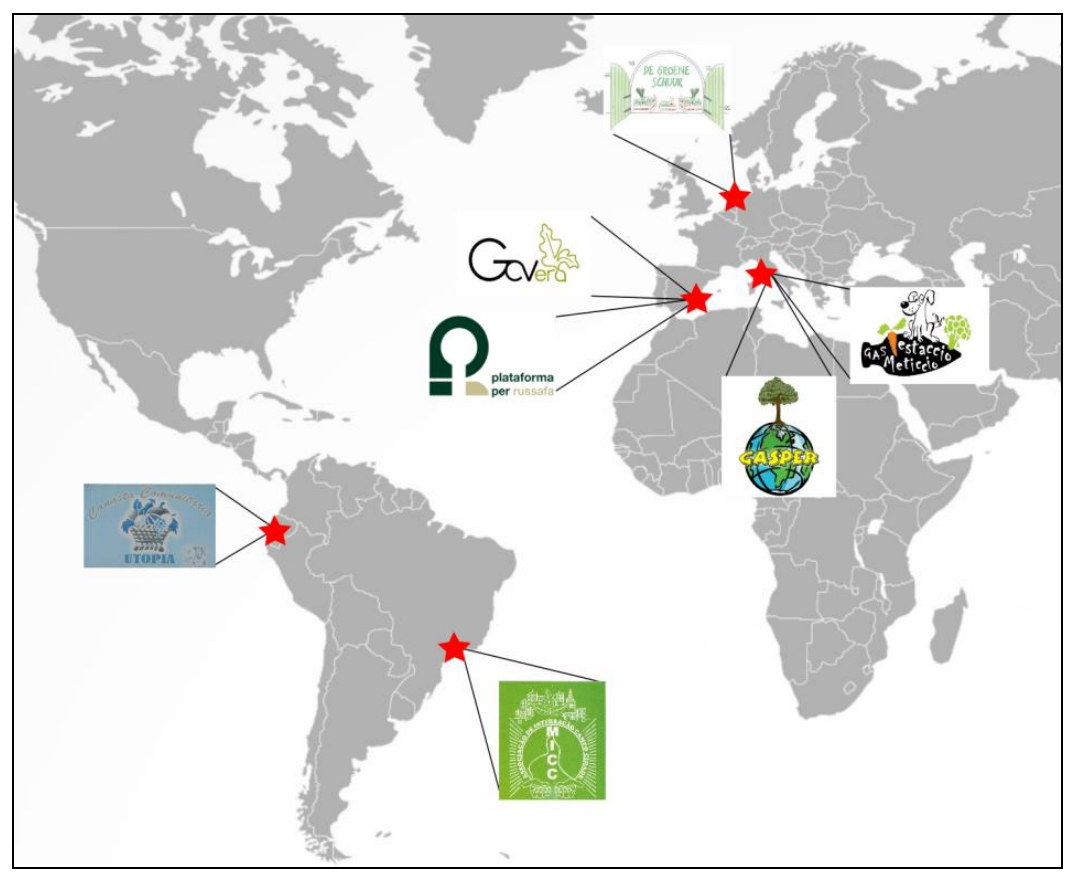

Figure 1. Location of the analyzed cases.

However, due to differences in scope and object, it was necessary to adapt the heuristic analytical fields to our study, especially because the original heuristic framework was developed to compare different types of food supply such as farm shops, farmers markets, box delivery schemes, community-supported agriculture and urban community gardens. Therefore, we used some of the fields from the original proposal, such as supply chain, food production methods and producer-consumer interaction. However we felt the need to add other fields that could better highlight potential similarities and differences between the cases of the particular type of food supply we explored and analyzed. Considering that we are working with cases from different countries, we include locality and origin as a way to clarify more the place and the circumstances that surround each experience. The ordering and the delivering form are complementary elements to the supply chain, and together tend to strongly influence the way each experience functions and how producers and consumers engage with each other. Given the important role of consumers in initiating and developing the CFAs we added a field dedicated to describe the consumers involved. Governance and networks are key elements to understand the arrangements at play, helping the alliances to be maintained. Legal entity is relevant to perceive the need, desire and possibilities for this type of food supply formalized within local laws. A more detailed description of each heuristic analytical field is presented below:

- Locality: Refers to the place where the case is active in geographical terms, but also considering the local circumstances that surround this place in terms of socio economic characteristics.

- Origin: Refers to how each alliance began, not only in terms of time but also the motivations that led actors to create it.

- Supply chain: Refers to the way food moves from the production site to delivery site where consumers access it. It may be constituted by a single supplier or multiple ones, which may range from: indigenous communities; family farmers (those who based the agricultural labor within family, and usually are involved in agriculture over generations); small farmers (those involved with farming activities, but not restricted to family ties regarding labor); social cooperatives and 
small business (small enterprises, such as bakeries, factories of homemade pasta, producers of wines and juices, producers of hygiene products).

- Food production methods: Addresses the ways food is grown and prepared, in particular in what terms actors involved perceive it and value it. Therefore, more than addressing techniques, it is important to clarify the perceptions of the actors about food and food quality. There is, among all cases, a strong valorization of pesticide free production methods that are expressed differently to each CFA and its site. For foods that involve some type of preparation, such as breads or cheeses, artisanal and small scale production techniques are the most appreciated.

- Ordering Form: This field refers to the way the food is ordered, which may happen in more interpersonal interactions such as face to face and through phone calls or by the use of on-line tools, such as specialized on-line software. This will affect not only consumer-producer interactions, but also the form of governance at play.

- Delivery form: Refers to how the food is delivered; there are mainly two options: closed food baskets or open order. The first implies that consumers receive a basket prepared by someone else, either the producers or a managing core of consumers. Thus, ultimately consumers do not choose what they will get. In the second form, consumers choose what they want from a list provided by producers.

- Consumers: This field presents a quantitative estimate about how many consumers are involved in the alliance. This estimate refers to family units, which can be individual households, groups of roommates or a family in a more traditional sense in terms of involving adult couples and children.

- Governance: Addresses the ways the CFA functions in terms of management tasks and decision making process, division of work regarding ordering and delivering, accountability and payments as well as the promotion of other activities besides food purchasing, such as socialization moments, educational events and political actions.

- Legal entity: This refers to whether the CFA is registered under legal requirements or it has an informal functioning. This is an important element because it addresses first how the actors perceive themselves as a collective actor and secondly because it approaches what the local possibilities for this kind of food supply are to be registered as a legal entity in its place of origin.

- Producer-consumer Interaction: This field presents different forms, spaces and occasions in which producers and consumers interact, it may be face-to-face or through various communications technologies such as phone calls, e-mail, and specialized software. This may happen in different spaces that vary from someone's home to headquarters or even public spaces, and at different occasions varying from delivery days, visit to farmers, shared meals, educational and cultural activities to political actions. More than describing forms and sites, this is relevant because it shows how relational those CFA initiatives are, involving material and symbolic, formal and informal encounters that affect the way relations are set and the outcomes that the food that circulates ultimately may represent.

- Network: This refers to the wider network of actors, beyond the producers and consumers, that are (in)directly involved in the alliance, such as the Catholic church, a wide range of social movements (indigenous, peasant, small farmers, slow food, agroecology), NGOs, and universities.

We believe that together, these fields create a clearer idea of how CFAs can foster sustainable urban-rural linkages and which of the ecological, social and economic dimensions are addressed in an interrelated way thought actors practices. For each initiative a table will be presented providing a synthesis of the heuristic analytical fields, followed by a more detailed description. 


\section{Results}

\subsection{MICC (São Paulo, Brazil)}

MICC stands for Movimento de Integração Campo-Cidade (Movement of Field and City Integration), it is located in São Paulo, a metropolis with 12 million inhabitants, situated in the most industrialized zone of Brazil. More precisely, its operation happens in the east side of the city, an area of greater social vulnerability. Table 1 provides a synthesis of the heuristic analytical fields for MICC. The activities began in the mid-1980s in a political context in which the country was just emerging from a dictatorial regime and there was an effervescence of social movements in both rural and urban areas. Due to a series of economic crises associated with unrestrained inflation and stagnation of economic growth, the socio-economic circumstances were quite hard in both rural and urban areas. On the one hand, agriculture modernization left many in the rural areas without work, leading these people to either stay in the field in precarious conditions or migrate to the cities in search for work in the growing industries. Among the rural workers who stayed, a group of peasants emerged who fought for the right to live as farmers and for the democratization of access to land. One of the main strategies used was occupying unproductive lands and pressing for agrarian reform, which they believed would help to improve people's living conditions allowing them to have a home and a piece of land to work on. This culminated in 1985 in the creation of the Landless Workers Movement (MST), now considered the largest social movement in Latin America.

Table 1. Heuristic analytical fields from MICC.

\begin{tabular}{cl}
\hline Heuristic Analytical Fields & \multicolumn{1}{c}{ MICC } \\
\hline Localization & São Paulo, Brazil \\
\hline Origin & Mid 1980 as a political collaboration among rural and urban workers \\
\hline Supply chain & $\begin{array}{l}1 \text { single supplier: APRI (Association of Rural Producers from Ibiúna), about } \\
25 \text { families }\end{array}$ \\
\hline Food production methods & "Without poison" \\
\hline Ordering form & Face-to-face, phone \\
\hline Delivery form & Closed food baskets \\
\hline Consumers & 800 family units \\
\hline Governance & $\begin{array}{l}\text { There is a managing core group and a network of volunteers connected to } \\
\text { each distribution point. }\end{array}$ \\
\hline Legal entity & Non profit Association \\
\hline \multirow{2}{*}{ Producer-consumer interaction } & $\begin{array}{l}\text { Delivery days, visit to farmers, shared meals, educational and cultural } \\
\text { activities, political activities }\end{array}$ \\
\hline Network & $\begin{array}{l}\text { Catholic Church, Messianic Church, public schools, public health centers, } \\
\text { small farmers movement, Landless Workers Movement (MST), indigenous } \\
\text { communities, Brazilian Network of Responsible Consumption Groups, } \\
\text { School and Citizenship Network }\end{array}$ \\
\hline
\end{tabular}

On the other hand, cities offered many opportunities for employment in the industry. However, because of poor working conditions, the workers began to organize themselves in search of regulation of working hours, minimum wage and the right to form unions that could support them. Thus, the cities became a field of major strikes led, especially, by metallurgical workers residing in the eastern part of São Paulo city. It is from the collaboration between these two movements that MICC emerged, supported by another movement active in both rural and urban areas. This movement is the Liberation Theology, a progressive movement within the Catholic Church that arose in Latin America around the late 1950s, having as its main goals to encourage people to have an active communitarian participation to address common needs. Thus, in the beginning, MICC was about food supply, but about gaining political support in the fight for basic human rights. 
At first, the city dwellers supported the MST by mobilizing resources and goods to aid land occupations with money, food, and clothing or simply by joining the occupations. The first food purchase occurs only in 1985, when in a collaborative action parishes and neighbors purchased an entire harvest of beans, equivalent to 30 tons. From then specific food purchases were made at harvest time, but sporadically. Only in 1993 after the acquisition of a vehicle MICC started to offer weekly baskets of vegetables, an activity that remains in force until today. Considering that São Paulo is a highly urbanized megalopolis, the food that urban population accessed was mostly offered by the expanding supermarket chains in the city. The cheapest alternative was farmers' markets or wholesale food markets, but that could mean a one-hour trip, something that can become unmanageable on a day-to-day basis. Thus, the direct purchase of food at the beginning was seen much more as a food security strategy, which provided urban consumers with affordable fresh food in a more practical way (close to home) and was a materialization of political and economic support to the peasant's movements. Thus, from the start improving the social and economic living and working conditions were the main issues that this CFA was addressing. Ecological sustainability was very insipient at the time, and only became a concern more recently with the growing public awareness about the impacts of agro toxics on people's health and the environment.

The baskets have about eight to twelve seasonal vegetables, provided by an Association of Small Rural Producers of Ibiúna (APRI), a family farmers' association from Ibiúna, located about $70 \mathrm{~km}$ from São Paulo (Figure 2). The products offered are, as they say, "without poison", a way of saying that they are produced without the use of agrochemicals, however they are not certified. The composition of the basket is chosen by producers according to product availability.

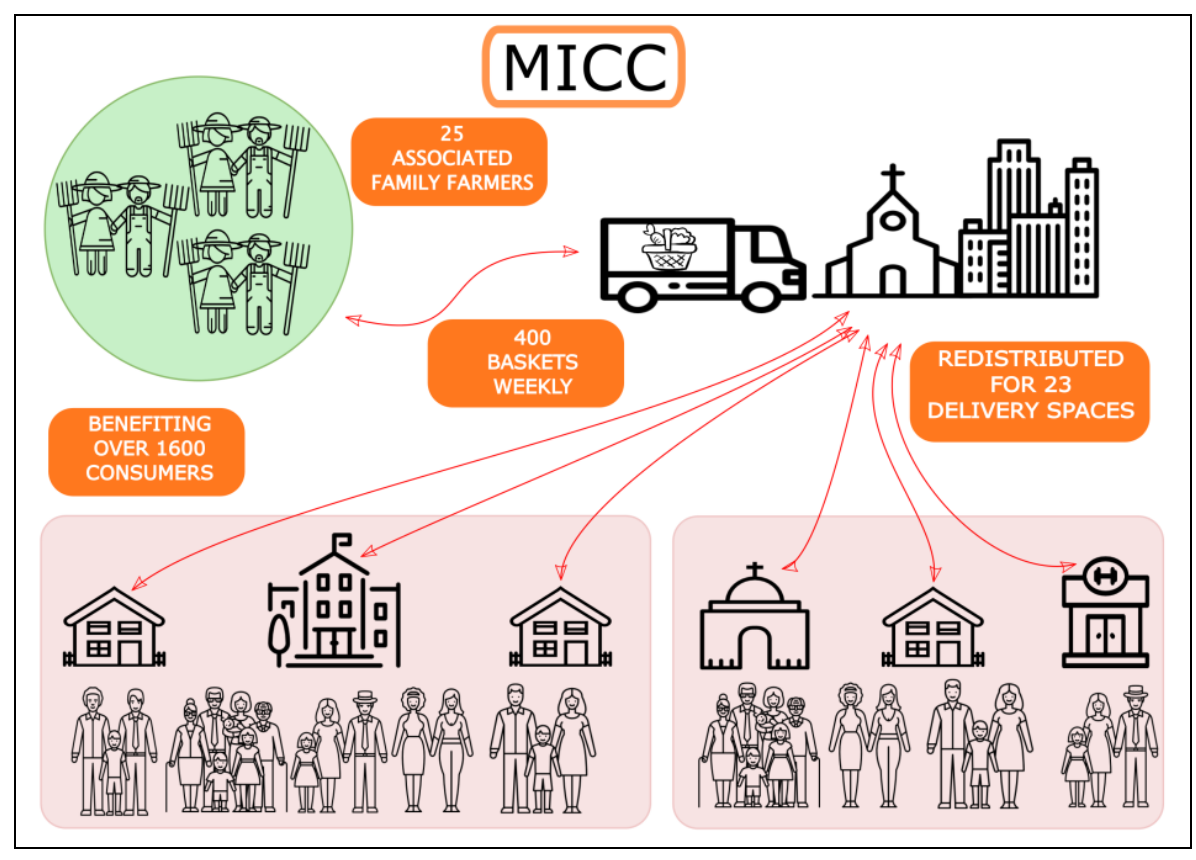

Figure 2. Supply chain dynamics of MIIC.

Deliveries always take place on Wednesdays to 23 distribution points dispersed around the East Side of São Paulo and include places like people's homes, basic health units, day care centers, gyms, pastoral seats, spiritual temples, Catholic and Messianic churches (Figure 3). Due to the number of baskets to be delivered benefitting around 800 family units; the distributions points were divided into two groups, therefore the consumers receive their food bi-weekly 


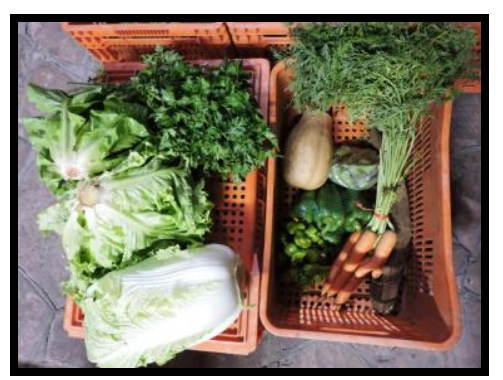

(a)

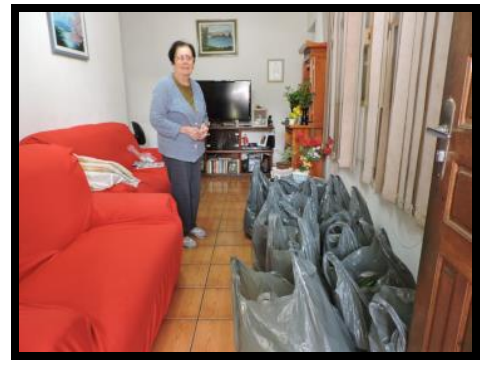

(b)

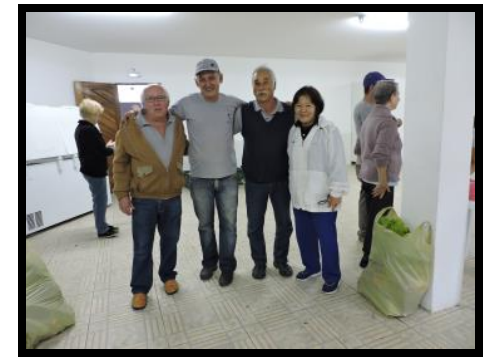

(c)

Figure 3. Vegetables Box (a); a distribution point at a consumer house (b); and consumers and producers at a delivery day at the Vila Ipiranga Church distribution point (c).

After registering to receive the basket, it is understood that the family wishes to receive the basket in a simple way, and in the case there is any unforeseen event that requires the delivery, this is done through a telephone call to the person responsible for the respective delivery point. The cost is US\$4.21, the amount paid is approximately one third of what they would pay for the same amount of conventional products at local farmers markets. It is relevant to say that the consumers belong mainly to low income social classes.

The governance involves a core group responsible for overseeing the whole process and liaising with producers. Each delivery point has a specific dynamic, some involve a small number of baskets (10-30) so may be controlled by just one person that receives the vegetables at her own house and redistributes to neighbors. Others, such as Vila Ipiranga Church or Vila Formosa Church, receive up to 100 baskets, so small groups of people are in charge of the receiving, distributing and delivering the baskets. Everything runs on a volunteer basis, each distribution point is run on a volunteer basis, where consumers become responsible for receiving and helping to redistribute to others. In 2008, the MICC was legally registered as a nonprofits Association, a need to facilitate procurement and invoice delivery to sites that purchase large quantities of products.

In addition to the baskets, MICC keeps a small warehouse in the courtyard of the Vila Alpina Church, where surplus products from the same farmers are offered, as well as natural medicine, and specific products from indigenous communities. MICC promotes education activities like culinary workshops that help people to eat healthily and economically, teaching recipes for integral use of food and natural cuisine. In partnership with the Rede Escola e Cidadania (School and Citizenship Network), they offer courses to schools distributed throughout São Paulo east side, encouraging citizenship, clarifying legal aspects of basic rights and furnishing guidelines on how to reach communitarian demands from the State. Visits to producers and celebrations are also held frequently creating a space for gathering and socializing between consumers and producers.

Considering the Brazilian scenario for such experiences, MICC stands out as the oldest and the largest initiative of this kind in the country. MICC belongs to the Brazilian Network of Responsible Consumption Groups, formed in 2011, which gathers a number of other experiences in the country and aims to articulate the groups politically as well as to facilitate joint actions among its members.

\subsection{Canasta Comunitaria Utopía (Riobamba, Ecuador)}

Canasta Comunitaria Utopía can be translated to "Community Food Basket Utopia". It is located at Riobamba city, one of the oldest and largest cities of the country at $2750 \mathrm{~m}$ above sea level in the Central Highland of Ecuador. It is the capital of the Chimborazo Province, one of the most important administrative, economic, financial and commercial centers of Ecuador. It has an active industry and a significant income from rural activities, such as the handicrafts of wool, hides and textiles, crops (barley, maize, bean, wheat, cacao, bananas, potatoes and some fruits), and livestock (sheep, beef, and dairy). Table 2 presents a synthesis of the heuristic analytical fields for Canasta Comunitaria Utopía. 
The origin of what today is called the Canasta Comunitaria Utopia dates back to 1987, with an initiative created by a group of families of the First Constituent, a workers' neighborhood dealing with economic precarity. Those families belong to the same parish of a Catholic Church, which at the time was under strong influence of the work of Bishop Leonidas Proaño, a national leader of the Liberation Theology movement. Inspired by these teachings, the families began to make their food purchases collective at San Alfonso market, enabling them to buy food in bulk, which turned out to be a more affordable food supply strategy than individuals shopping at local markets. After purchasing, the group met at one of the residents' houses to pray, socialize and divide the food among the families. The group followed this practice for ten years, and then dissolved for different reasons.

However, in 1998, some of the families that had participated in the aforementioned initiative of collective purchasing joined the Collective Utopia, a group recently formed by agronomy students with the goal of supporting indigenous communities through technical assistance. Thus, in addition to providing the urban families with food, the Collective Utopia also implied political and economic support for the indigenous communities, which were highly marginalized in mainstream markets. To this end it is important to clarify that historically there has been a tension between two parts of the population, the Spanish descendants and indigenous people, with the latter in an inferior socioeconomic position and generally acting as servant of the other part of the population.

Table 2. Heuristic analytical fields from Canasta Comunitaria Utopía.

\begin{tabular}{|c|c|}
\hline Heuristic Analytical Fields & Canasta Comunitaria Utopía \\
\hline Localization & Riobamba, Ecuador \\
\hline Origin & $\begin{array}{l}\text { Mid 1980, as a joint action among families from the same neighborhood } \\
\text { to purchase affordable food }\end{array}$ \\
\hline Supply chain & $\begin{array}{l}\text { Multiples suppliers: Indigenous, communities, family farmers, } \\
\text { Associations of Food Processing, Mercado Mayorista }\end{array}$ \\
\hline Food production methods & Conventional, agroecological, low chemicals input \\
\hline Ordering form & Face-to-face, phone \\
\hline Delivery form & Closed Food baskets \\
\hline Consumers & 60 family units \\
\hline Governance & $\begin{array}{l}\text { Managing staff, a core council and consumers take turns helping in } \\
\text { deliveries }\end{array}$ \\
\hline Legal entity & Consumers Association \\
\hline Producer-consumer interaction & $\begin{array}{l}\text { Delivery days, visit to farmers, shared meals, educational and cultural } \\
\text { activities, political activities }\end{array}$ \\
\hline Network & $\begin{array}{l}\text { Catholic Church, Red Canastas Comunitarias y Solidarias, Movimiento de } \\
\text { Economía Social y Solidaria del Ecuador (MESSE), Colectivo Agroecológico, } \\
\text { Fundación Ekorural, agroecological movement, indigenous movement }\end{array}$ \\
\hline
\end{tabular}

Thus, the practice of purchasing food in bulk by the Collective Utopia was partially a strategy to help the urban working class to have their food supply. In addition, buying directly from indigenous communities was also a strategy to foster better living conditions for these communities by setting up a stable market and with more solidary relations, as well as to value locally produced products. With time, the initiative grew to 300 families in 2002 and it legally became a consumer association. They have also influenced that emergence of similar initiatives all over the country. Through this process links between consumer groups and the agroecological movement active in the south of the Ecuador were established. This encounter has influenced Canasta Comunitaria Utopia to pay more attention to the production methods involved and to value agroecological products, making ecological sustainability a topic of concern.

Today, the Canasta is concerned with offering a basket with food considered basic for the local diet, so its chain of supply involves multiple suppliers. Part of the food is purchased in direct arrangements with producers, and involves two indigenous communities, a few family farmers, 
and one Associations of Food Processing (ACT). However, complements the purchases in a wholesale market, Mercado Mayorista, where it searches for foods that could not be supplied directly by the producers. The priority is given to agroecological products especially considering the direct purchase with producers, but occasionally some conventional food is offered to, it varies accordingly to season and availability of products.

The baskets are delivered bi-weekly at the street in front of Fundación Utopía headquarters and, supposedly, it is enough to feed a family of five people for two weeks. The baskets are closed, meaning that the choice of what products will be delivered each week is made by the management team that seeks to balance the products available with a variety of vegetables, fruits, flours and grains. Just like MICC, after registering, the family will receive the basket unless it cancels it through a telephone call or face-to face meeting. Although there is only one distribution point, Canasta currently benefits about 60 family units. Consumers organize themselves in a system of rotation to assist in the preparation of the baskets and delivery. The baskets are closed and have between 20 and 23 items and cost US\$1200. From that, US $\$ 0.50$ is used for the office and US\$1.00 for a collective fund. Figure 4 illustrates the supply chain.

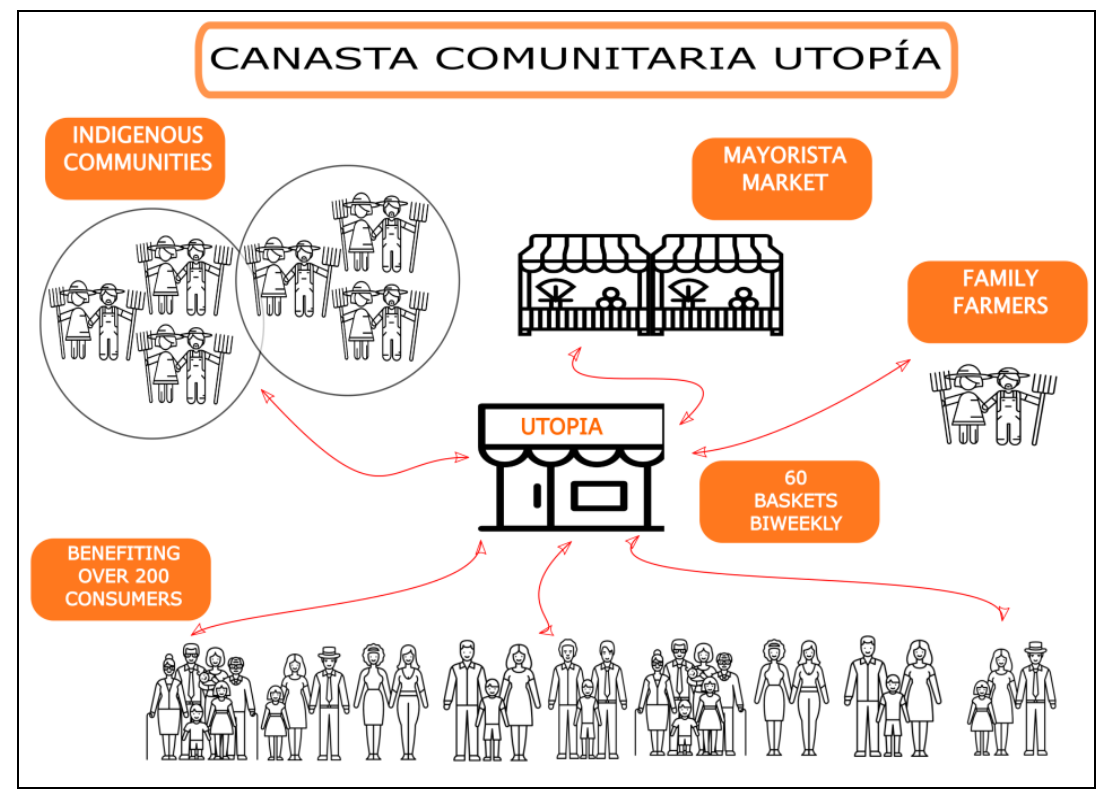

Figure 4. Supply chain dynamics of Canasta Comunitaria Utopía.

As far as governance goes, there is a group of consumers called Grupo Zero, whose function is to support logistical and administrative decisions. This group is elected in assembly, an event that occurs at least once a year. The staff has two people working for the association, who are responsible for overseeing the process, comparing food and maintaining contact between consumers. All the rest of the work takes place on a voluntary basis.

Delivery days are long, since the day starts at 6:00 a.m. and its goes until 12:00 p.m. During this time where producers arrive with products and consumers groups guided by the staff work on assembling the baskets people share meals, talk and quite often dance to the sound of regional music (Figure 5). Therefore, it is a highly social moment. An internal research about consumer's motivation showed that the social relations fostered in the group are more valued than nutrition and health aspects that the food may provide. The group also makes organized visit to farmers, workshops and lectures about food security. 


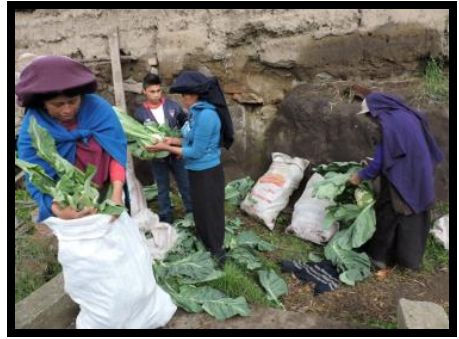

(a)

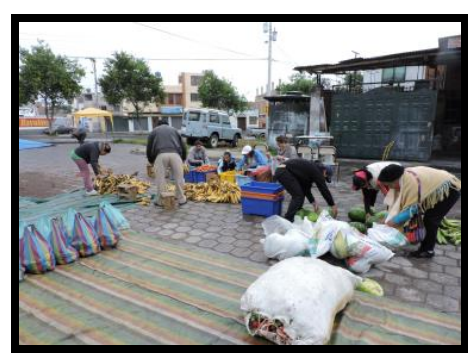

(b)

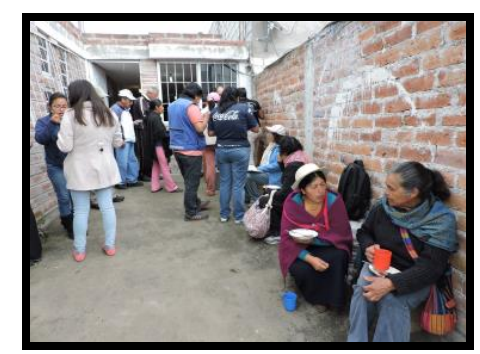

(c)

Figure 5. Farmers from the indigenous community of Tzimbuto preparing the products for the Canasta (a); consumers organizing the food baskets (b); and consumers and producers socializing in a delivery day (c).

Canasta Utopia plays a prominent role in the country, since it is the oldest of this kind of food supply, so it inspired other similar initiatives that ultimately lead to the creation of a national Network-Red Canastas Comunitarias y Solidarias in 2004. This network allowed an enrichment of the experiences by the exchange of practices and values in the group's repertoire such as food sovereignty, solidarity economy and agroecology. The strength of the Network led to a political recognition that allowed the Canasta to have an active participation in drafting the new Constitution of the country in 2007, especially in the laws on food sovereignty and agroecology.

The national network no longer exists, but most of its members are still active and working for the quite close causes in another network also acting nationally now called Colectivo Agroecologico that is quite active nationwide and promotes a campaign called " 250 thousand families that eat rich, healthy and from our land" that aims to foster a change in the populations eating habits towards local, sustainable and socially just food provision. They are also connected to other social movement, especially Movimiento de Economía Social y Solidaria del Ecuador (MESSE), the country agroecological movement and the indigenous movement, as well as the NGO that works with rural development such as Fundacion Ekorural.

\subsection{Gruppo d' Acquisto Solidale Testaccio Meticcio (Rome, Italy)}

The English translation for Gruppo d' Acquisto Solidale (GAS) would be Solidarity Purchase Group. GAS emerged in Italy in the 1990s as part of a food re-localization movement that aims to establish different economic and social relations between producers and consumers. The rise of GAS is embedded in a wider anti-globalization movement that sees the global energy crisis, climate change, the finite character of resources and social disparities as a result of neoliberal policies, in particular the unregulated political power of multinational corporations and the deregulated financial markets. Promote actions at local level on daily basis are perceived as expressions of active citizenship advancing social justice, human rights, solidarity market relations and sustainable development. GAS are understood as a form of supply where consumers can get healthy, sustainable food at affordable prices, while helping small famers to have a guaranteed market. These solidarity relations are combined with a focus on more ecological methods of production, fresh food and spatially proximity between sites of production and consumption. A synthesis of GAS Testaccio Meticcio heuristic analytical fields is presented at Table 3.

Testaccio is one of the regions of the city of Italian capital Rome. Traditionally Testaccio is a working class neighborhood, but in recent years it is becoming a more popular touristic place, as a gastronomic and cultural venue. Meticcio is Italian for metis, so it is an analogy for the group diversity. The GAS Testaccio Meticcio started in 2011, as an initiative of Alfredo, a young professional in informatics, who had already participated in another GAS since 2009. He was not satisfied with the governance system at play which has a more centralized structure, so he decided to create a new GAS. He placed announcements in the neighborhood streets and Internet, at first a group of ten people 
replied and soon got together to define their guidelines. Today, they have around thirty-five families of consumers, mainly middle-class, with a high variation of professional backgrounds. All consumers live within walking distance or small bike-ride from the delivery point at the "Casa de lla Sinistra", the headquarters of a left socialist political party Sinistra Ecologia Libertà (SEL). Important to say that there is only one person from this party participating in the GAS, so the partnership is restricted to the use of space, and there is no impact on the political orientation of the group as a whole, that actually claims to do "politics without parties".

Table 3. Heuristic analytical fields from GAS Testaccio Meticcio.

\begin{tabular}{cl}
\hline Heuristic Analytical Fields & \multicolumn{1}{c}{ GAS Testaccio Meticcio } \\
\hline Localization & Rome, Italy \\
\hline Origin & 2011, by the initiative of one person that mobilized its neighbors \\
\hline Supply chain & $\begin{array}{l}\text { Multiples suppliers: family farmers; small farmers, social cooperatives } \\
\text { and small business }\end{array}$ \\
\hline Food production methods & Organic, artisanal, and small scale \\
\hline Ordering form & On-line software \\
\hline Delivery form & Open order \\
\hline Consumers & 35 family units \\
\hline Governance & Horizontal self management, with rotation of key task among members \\
\hline Legal entity & GAS \\
\hline Producer-consumer interaction & $\begin{array}{l}\text { Delivery days, visit to farmers, shared meals, educational and cultural } \\
\text { activities, political activities }\end{array}$ \\
\hline Network & $\begin{array}{l}\text { Sinistra Ecologia Libertà (SEL), Rete GAS, Slow Food Movement, Rete di } \\
\text { Economie Solidali }\end{array}$ \\
\hline
\end{tabular}

The group governance follows a very horizontal structure of self management, with rotation of key task among members: coordination (an overseeing and spokesman role), accounting, liaison with suppliers, promotion of events, communications. Each participant must engage in a task, besides taking turns to assemble baskets and deliver them. The task division is defined monthly at the group meetings. In addition, the participants frequently meet each other for farm visits, dinner, cooking parties or debates.

Food delivery takes place weekly on Thursdays nights, ranging from fresh vegetables, fruits, honey, jams, yogurt, cereal, pasta, biscuits, cakes, meat and cheese (Figure 6). They also buy hygiene products and art crafts. The orders are made through software developed for this purpose and are open, meaning each family chooses what each wishes for each week according to the products available. Therefore they have multiple suppliers, from family farmers, small farmers, social cooperatives and small businesses; the process is illustrated by Figure 7 .

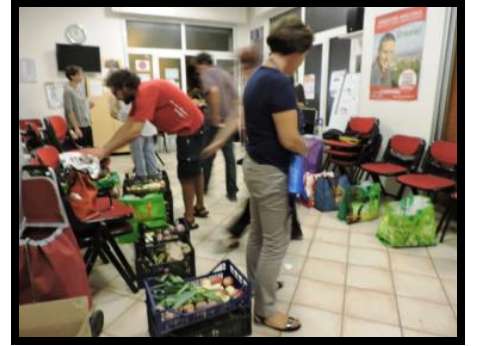

(a)

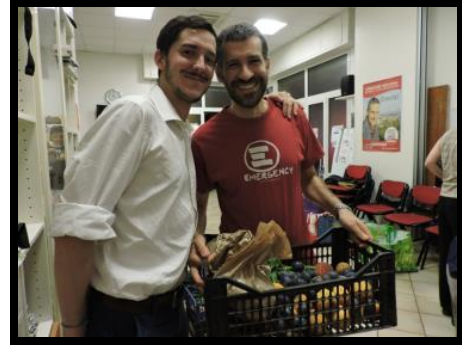

(b)

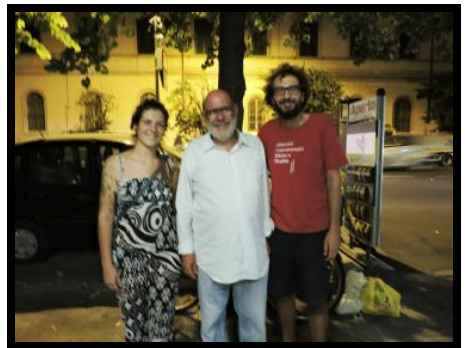

(c)

Figure 6. Consumers organizing the orders at a delivery day (a); two consumers showing a box of products and (b); Alfredo the initiator of the GAS together with two farmers (c). 


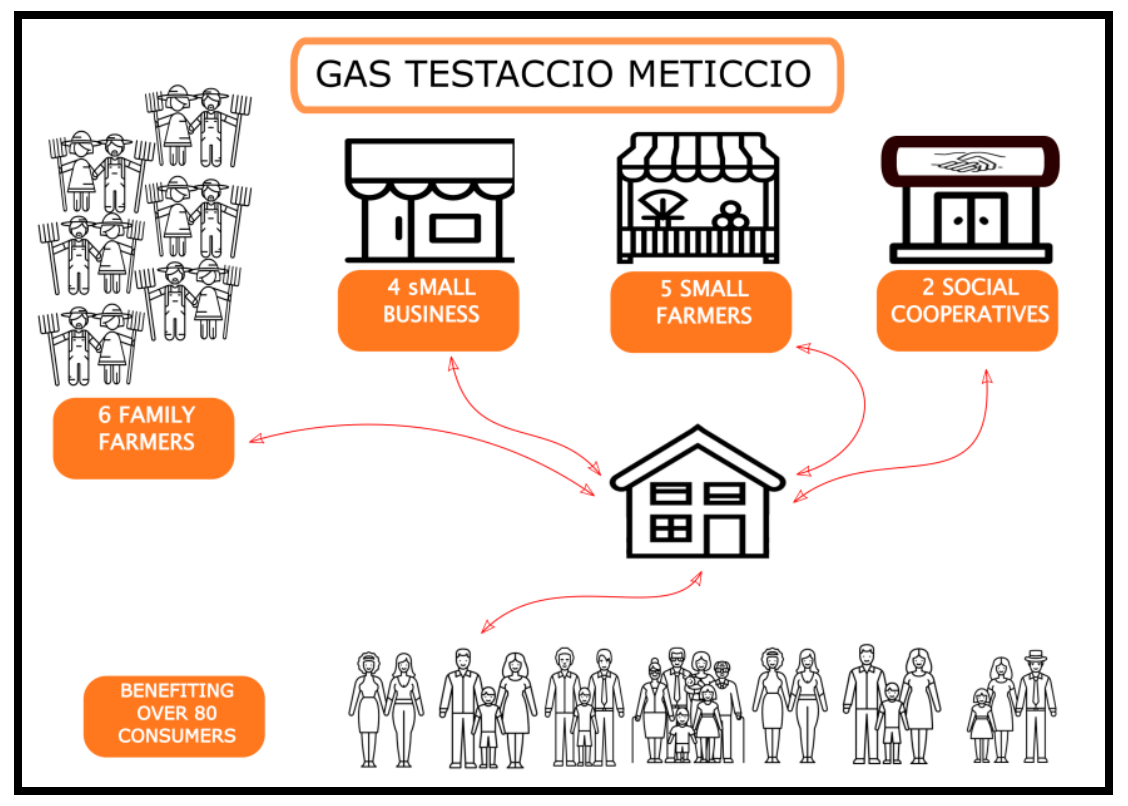

Figure 7. Supply chain dynamics of GAS Testaccio Meticcio.

There are four main criteria for choosing suppliers: (1) locality, so they try to be "Kilometer Zero" as much as possible, making partnership with small local businesses or famers located at Rome nearby rural area; (2) genuineness, all products must be cultivated with Biological and natural methods and when products involve processing there is a preference for artisanal production; (3) eco-compatibility, they favor the goods without packaging or that use recyclable materials; and (4) solidarity, meaning that selection also takes into consideration the social commitment of suppliers in terms of contributing to fight against the exploitation, poverty, or other economic, political and social matters.

An example of this last item is the yogurt supplier Barikama, a Social Cooperative born in 2011 by five young men from Sub-Saharan Africa. After immigrating to Italy they ended up working in the plantations of oranges and mandarins fields of Calabria in subhuman conditions. After suffering a racist attack when they were shot, they escaped to Rome and spent some time "living" at Termini train station before going to the social center ex-Snia. From there they started to produce yogurt in a very informal way to raise some money. Some GAS members bought it and soon enough the product was being sold at the GAS itself. In addition, the community of GAS encouraged them to formalize their entrepreneurial activity and helped them to raise money. Today the personal situation of Barikamà's founders is much better; they produce $150 \mathrm{~L}$ of yogurt per week and are organic certified by a partnership with Casale di Martignano, a local cheese factory. They welcome other immigrants struggling to find employment, so besides income and social inclusion, it is an experience that helps restore the personal confidence of people in precarious situations, creates a network of social relationships to learn Italian and to integrate into the city.

More recently, the Barikamà established a new partnership and started working in the vegetable cultivation in La Nuova Arca, another GAS supplier. They are also a social cooperative and have a two hectares property, $25 \mathrm{~km}$ outside the city. The land is used for organic production of vegetables grown by unemployed immigrants and young offenders who can learn a new craft. Through the project Tent of Abraham, single mothers in need find not only a home, but also a space where they can generate income in a flexible routine that allows them to combine work with childcare. Besides Testaccio Meticcio, la Nuova Arca supplies thirty others in the city. These are just two suppliers, but they show that the choice of suppliers goes beyond a matter of proximity, price or organic certification, but also involves the desire to directly support initiatives that have a wider social impact. This is what participants refer to when they say they do "politics without parties". 
They are legally registered as a GAS, which became recognized by the Italian law in December 2007, as "non-profit associations set up to carry out collective purchase and distribution of goods for ethical, social, solidarity and environmental sustainability purposes" ([22], p. 6). This is an important element, since, besides Italy, France is the only other country that recognizes this kind of initiative as a legal entity, but, in this case, it refers to the AMAPs.

They are connected to the Rete Nazionale Dei Gruppi D'acquisto (Rete GAS) (National Network of Solidary Purchase Group), founded in 1997 and up to today it plays an important role in demonstrating these experiences. Besides promoting meetings to reflect on the exchange experiences, it holds a website where GAS all over the country can be found, as well as models of documents for setting up initiatives. They are also connected to the Slow Food Movement and the Rete di Economie Solidali (RES), the national solidary economy network.

\subsection{Gasper (Rome, Italy)}

This GAS is also located in Rome, Italy, but it supplies people resident in the San Lorenzo neighborhood, a quarter built in the nineteenth century to house workers coming to the city in a period of expansion, but which was the part of the city most damaged during the bombardments of World War II. Today, it is considered a popular and university district, characterized by its many social centers, cultural associations and a vibrant nightlife.

Gasper was started in 2008 by a small group of neighbors interested in buying direct from local producers tuned into an ethical framework of ecological agriculture connected to a fair and solidary economy. Table 4 provides a synthesis of the heuristic analytical fields for Gasper. Similar to GAS Testaccio Meticcio there is a concern about the marginalization of farmers by the mainstream food supply and a strong wish to avoid products from multinational corporations and supermarket chains, since they are perceived by actors as promoters of ecological degradation and social inequality. The group has approximately fifty families of consumers that purchase food provided by multiply suppliers that range from family farmers; small farmers, social cooperatives and small businesses. Deliveries take place on a weekly basis, always on Friday night, in an open order dynamic that is facilitated by on-line software (Figure 8).

Table 4. Heuristic analytical fields from Gasper.

\begin{tabular}{cl}
\hline Heuristic Analytical Fields & \multicolumn{1}{c}{ Gasper } \\
\hline Localization & Rome, Italy \\
\hline Origin & $\begin{array}{l}\text { 2008, by a group of neighbors interested in buying direct from local } \\
\text { producers }\end{array}$ \\
\hline Supply chain & $\begin{array}{l}\text { Multiples suppliers: family farmers; small farmers, social cooperatives } \\
\text { and small business }\end{array}$ \\
\hline Food production methods & Organic, artisanal, and small scale \\
\hline Ordering form & On-line software \\
\hline Delivery form & Open order \\
\hline Consumers & 50 family units \\
\hline Governance & Horizontal self management, with rotation of key task among members \\
\hline Legal entity & GAS \\
\hline Producer-consumer interaction & $\begin{array}{l}\text { Delivery days, visit to farmers, shared meals, educational and cultural } \\
\text { activities, political activities }\end{array}$ \\
\hline Network & $\begin{array}{l}\text { Rete GAS, Slow Food Movement, Rete di Economie Solidali (RES), } \\
\text { organizations connected participatory certification, food sovereignty }\end{array}$ \\
\hline
\end{tabular}




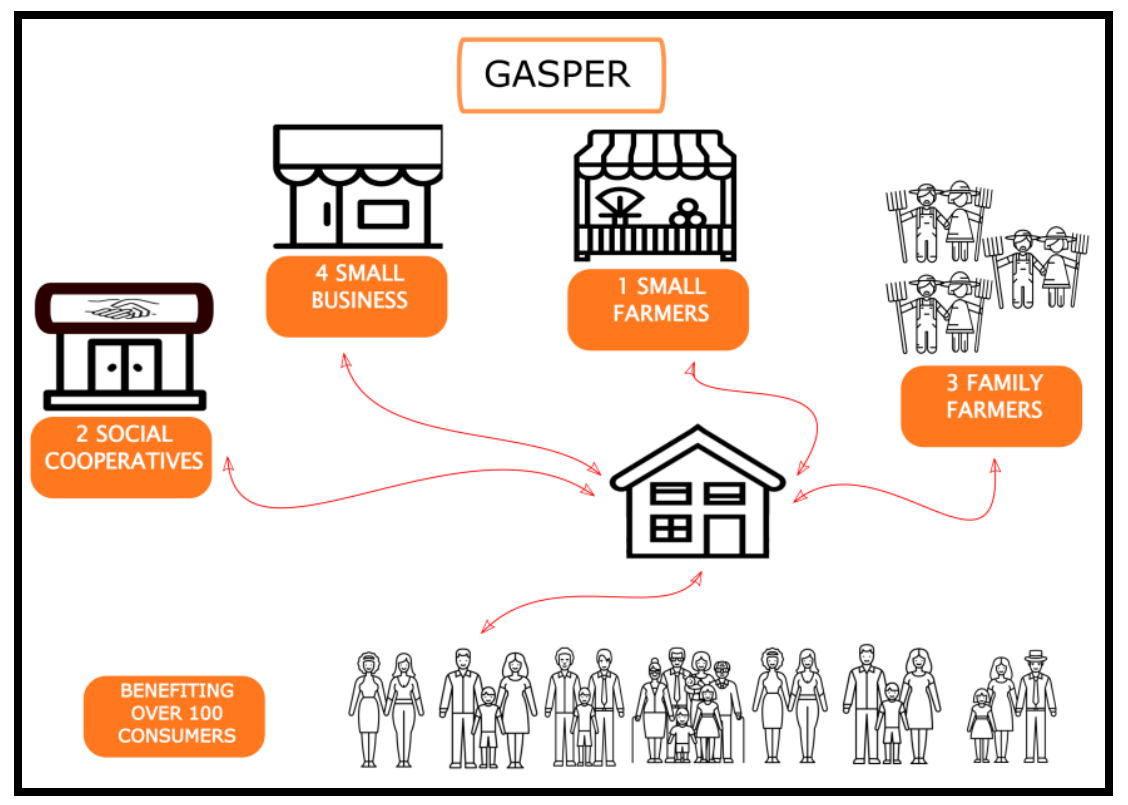

Figure 8. Supply chain dynamics of Gasper.

They have a big variety of products that are delivered with different frequencies; this makes the process of ordering a bit tricky, because the different products have different deadlines to be requested, demanding consumer's time and a good organization. For instance, fresh vegetables are delivered weekly, bi-weekly there are eggs and fresh pasta, once a month they have products such as: oil, olives, pickles, flours, jams, pasta, cheese, yogurts, meats, wine, fruit and dried vegetables, honey, cereals, liquors, baked goods and sweets. Other products are in accordance with the availability, specially the seasonal fruits. However, the wide variety of products seeks to enable consumer families to supply the majority of their food needs through GAS, thus avoiding consuming in other marketing channels, especially supermarkets.

For each delivery day, three consumers must volunteer to organize the dynamics, from checking the products that arrive, separating the orders and receiving the money (Figure 9). Participants also must pay a fee of $€ 50.00$ to join the group and $€ 2.00$ per month to pay the rent of the place. The group governance also follows a horizontal structure of self-management, with rotation of key tasks among members: accounting, ordering, liaison with suppliers and communications. Gasper values food as something that must be shared and experienced in quite a pleasurable way, so they close each delivery with a dinner in which everybody is welcome to join. This is facilitated by the fact that deliveries happen at Come se, an architecture gallery that also works as a vegan restaurant in the evenings.

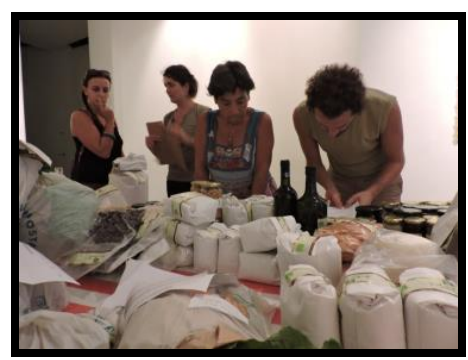

(a)

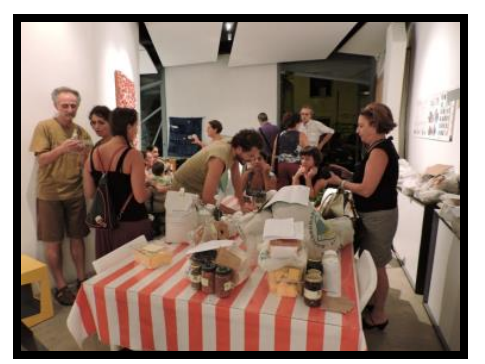

(b)

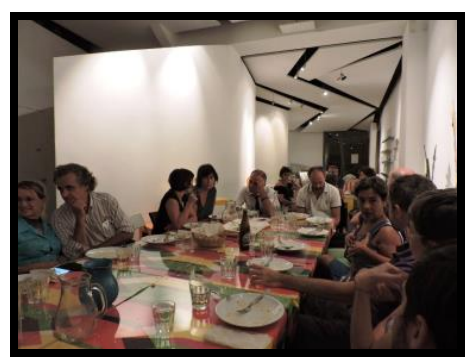

(c)

Figure 9. Consumers organizing people's orders $(\mathbf{a}, \mathbf{b})$; and consumers having dinner after a delivery day $(\mathbf{c})$. 
Visiting farmers is a common practice among the group that also frequently pre-finance harvests of products to be sold in the group. They express the same kind of concern as GAS Testaccio Meticcio by choosing suppliers that besides products can provide social impact, but they highlight the idea of being supplied by contadini un vero, meaning the "real farmers" who live from and for the land. They also partner with some suppliers, such as Barikamà, Liberovo, a family farmer who delivers eggs; Amor di Pasta, an artisanal pasta producer; and Fattoria Il Papavero, a small fruit farmer. However, it also contributes to different projects as is the case of L'Orto Magico which is a project that involves seeking inclusion through gardening for people with Down syndrome and other mental disabilities.

Besides, being actively engaged in the Rete GAS from Lazlo province, the group participates and incentivizes its members to be active in other initiatives such as Slow Food Movement, the national solidary economy network, as well as well as organizations connected with participatory certification and food sovereignty.

\subsection{Grupo de Consumo Vera (Valencia, Spain)}

The Grupo de Consumo Vera is located in Valencia, on the Spanish Mediterranean coast; it is the capital of the homonymous province and considered the third most populous city in the country. More specifically, it operates within the Polytechnic University of Valencia (UPV), an educational institution focused on science and technology with a wide range of graduation and post-graduation programs. A synthesis of the heuristic analytical fields for Grupo de Consumo Vera can be found at Table 5.

Table 5. Heuristic analytical fields from Grupo de Consumo Vera.

\begin{tabular}{cl}
\hline Heuristic Analytical Fields & \multicolumn{1}{c}{ Grupo de Consumo Vera } \\
\hline Localization & Valencia, Spain \\
\hline Origin & $\begin{array}{l}\text { 2012, by group of people from UPV interested in buying food straight } \\
\text { from producers }\end{array}$ \\
\hline Supply chain & 2 main suppliers (family farmers), two small local businesses \\
\hline Food production methods & Organic, artisanal, and small scale \\
\hline Ordering form & Excel sheet \\
\hline Delivery form & Open order \\
\hline Consumers & 50 family units \\
\hline Governance & $\begin{array}{l}\text { Horizontal self management, with commission responsible for specific } \\
\text { tasks }\end{array}$ \\
\hline Legal entity & Cooperative \\
\hline Producer-consumer interaction & $\begin{array}{l}\text { Delivery days, visit to farmers, shared meals, educational and cultural } \\
\text { activities, political activities }\end{array}$ \\
\hline Network & $\begin{array}{l}\text { Polytechnic University of Valencia, Fundación CEDAT, Grupo a Grupo, } \\
\text { La Plataforma per la Sobirania Alimentària }\end{array}$ \\
\hline
\end{tabular}

It started in 2012 with a group of people from UPV, some already working in the agrifood field, who besides being active in the $15 \mathrm{M}$ were interested in buying local, fresh, organic food straight from producers. The $15 \mathrm{M}$ is the anti-austerity movement that started on 15 May 2011 in Spain, where people started to occupy public areas to peacefully protest against the economic crisis and the Spanish two-party system. This action spurred a series of other occupations all over the country, with people calling for a "real democracy through citizen's action" by demanding basic rights as a way to address the high unemployment rates and the welfare cuts. In some ways $15 \mathrm{M}$ had similar concerns as the aforementioned anti-globalization movement, in the sense that the government's program of economic reform is dictated by IMF neoliberal politics, which ultimately privilege multinational corporations and financial markets, jeopardizing basic rights of society and people's quality of life. After months of 
occupation and demonstrations, $15 \mathrm{M}$ had encouraged many people to play a more active role in their own neighborhoods-los barrios. Thus, people began to collectively focus on improving the public infrastructure and the welfare needs of the population.

The Grupos de Consumo aim to supply the urban population with clean, fresh, local and affordable food, while also creating the possibility for local farmers to generate income. Hence, the Grupos de Consumo intend to foster the socio-economic sustainability of both urban residents and farmers. In addition, in the case of Valencia, several ecological concerns are being addressed, in particular production methods and preservation of rural areas in the city's surroundings-the huertos. These peri-urban and rural farmlands used to be main areas for urban food provision. However, since the 1960s, these farmlands increasingly became a site for urban development, which lead to a degradation of the environment and the loss of local farming and food cultures. With the recent economic crisis, the process of urbanization slowed down, allowing some of the huertos to remain. Hence buying from local producers is also understood as a social and ecological stance supporting the conservation of those environments and communities.

The Grupo de Consumo Vera started as the result of an email sent to a group of people from the University indicating a date when those interested in direct food supply could meet. About 30 people attended at the start and after that it took a few meetings to structure the dynamics of the operation of the group. Today, there are around fifty consumer families in the group, of which about thirty order weekly. To join consumers must have some connection with the University, and so should be a teacher, student, employee or worker at the campus.

They have four suppliers: two family farmers who offer products such as vegetables, fruits, yogurt, cheese, eggs; and two small local businesses that deliver bread and craft beer (Figure 10). The food distribution takes place weekly on Wednesday afternoons. The orders are made through an Excel sheet in accordance with the products available; therefore, the consumers can choose what to order. Each week three consumers are responsible for receiving the products, separating the orders and distributing the boxes (Figure 11). Food delivery takes place at a warehouse of the Fundación CEDAT (Special Employment Centre of the Polytechnic University of Valencia) which works for the social integration of people with disabilities.

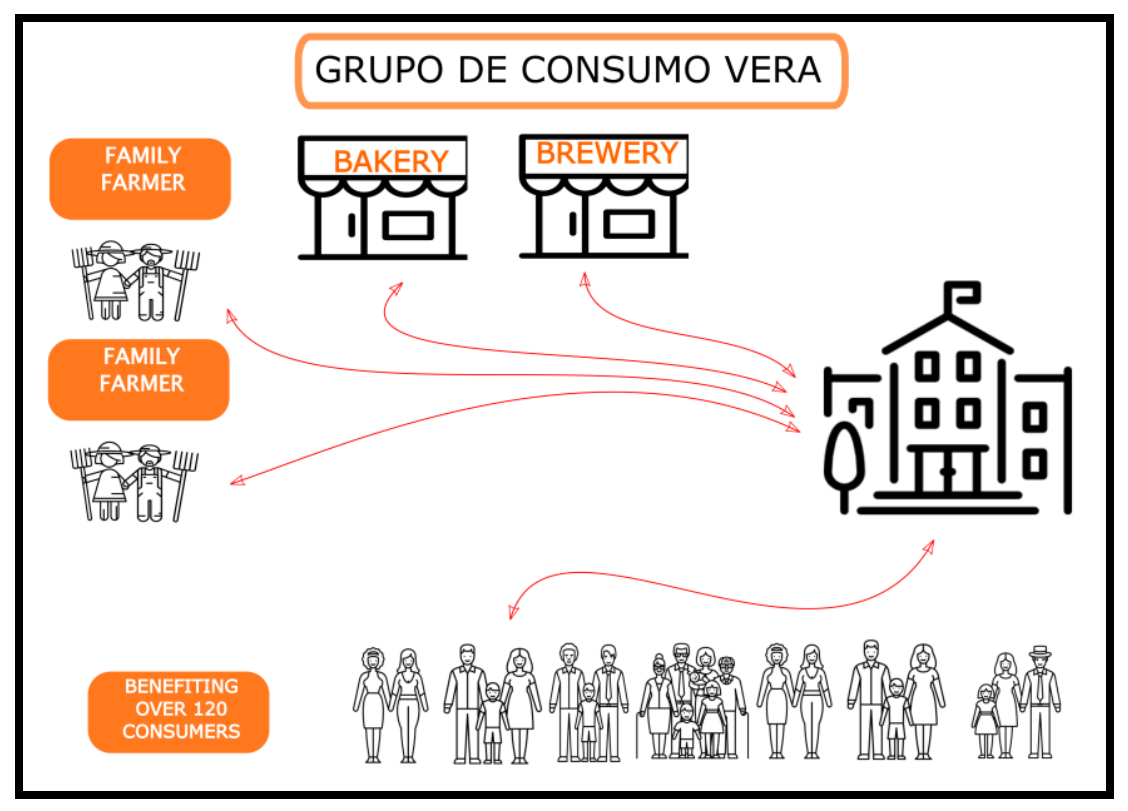

Figure 10. Supply chain dynamics of Grupo de Consumo Vera. 


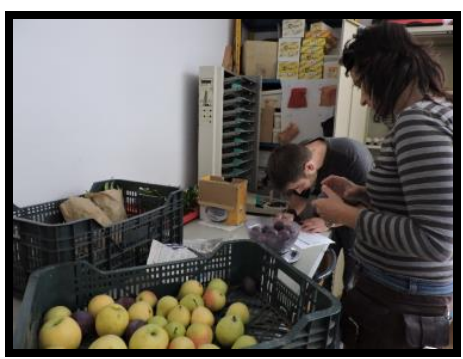

(a)

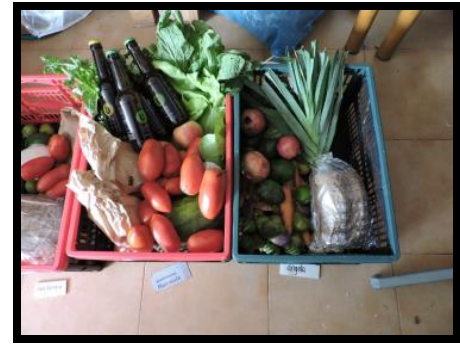

(b)

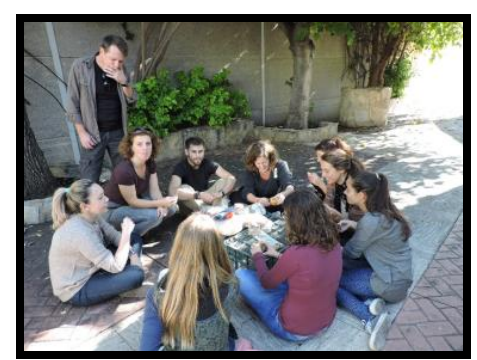

(c)

Figure 11. Consumers organizing the orders (a); food boxes (b); and consumers tasting products of a possible new bread supplier (c).

The governance is based on a horizontal self-management structure, with a commission responsible for specific tasks: logistics, liaison with producers, welcoming, economics and "incendiaria" (networking and political action). Thus, all participants must join one of the commissions besides committing to collaborate in the deliveries every two months. The group decisions are taken in assemblies every three months. In addition, they have a joint bank account that they use to make payments for the products at the end of each month.

It is worth mentioning that the functioning of the group occurs in a very informal way. An example is the choice of a new supplier, which, despite the need to fulfill the group's criteria, takes place in a very relaxed way that looks more like a picnic, where the products are tasted in a conversation circle. They also organize visits to farmers, get together for shared meals, as well as promoting more educational and cultural activities concerning food and the situation of the local farmer. In this sense they stress the relevance of the group in helping to dignify farmers who live in the rural area of Valencia.

They are legally registered as a cooperative, but have a strong claim that the consumption groups should be recognized by the Spanish law, like the GAS and AMAP's initiatives. They understand that they live in a context of "illegality" that limits their performance, because it makes it difficult for them to access products such as meat and fish that require a refrigerated storage structure or emission of receipts. Another limitation is the difficulty in acquiring insurance for its members, including producers who could have accidents when transporting products.

Together with CEDAT, the group also organizes a weekly vegetable basket with local products to be delivered to university staff. The basket is organized by people with disabilities that are connected to CEDAT through projects that aim to provide income and social inclusion. The products are delivered by the same two family farmers that supply the Group with vegetables.

They network with other local actors involved in sustainable consumption practices and food sovereignty. One is the Grupo a Grupo, a network that gathers other consumer groups to exchange experiences and promote join action. They have developed a webpage where it is possible to find information on the functioning of groups. Free software is offered to facilitate orders and a map of consumer groups active in the country and their suppliers help them to keep connected. They also belong to the La Plataforma per la Sobirania Alimentària del País Valencià (The Platform for Food Sovereignty in the Valencian Country), a political forum that involves experiences beyond consumption groups and aims to facilitate collaboration and foster actions towards Food Sovereignty.

An example is an activity held annually on 17 April, the International Day of Peasant Struggle when all the groups deliver their baskets on the street or other public places as a way to call people's attention to the political dimensions of consumption, the local farmer's situation and food sovereignty. It is interesting to highlight that the date was chosen in memory of the Eldorado dos Carajás massacre, when nineteen peasants from the Brazilian Landless Workers Movement (MST) were killed by the police force, after occupying a private unproductive land in Southern Pará state, in 1996. 


\subsection{Grupo de Consumo de Russafa (Valencia, Spain)}

The Grupo de Consumo de Russafa is also located in Valencia, Spain. The area was considered as an independent municipality until 1877 when it was integrated with Valencia as a district. The neighborhood is known as a popular and traditional space that brings together many workers and an active cultural life, but in recent years it is undergoing a process of gentrification and increased tourism, putting pressure on the local population and small businesses. Table 6 provides a synthesis of the heuristic analytical fields for Grupo de Consumo de Russafa.

Table 6. Heuristic analytical fields from Grupo de Consumo de Russafa.

\begin{tabular}{cl}
\hline Heuristic Analytical Fields & \multicolumn{1}{c}{ Grupo de Consumo de Russafa } \\
\hline Localization & Valencia, Spain \\
Origin & 2011, by neighbors connected with Platform Per Russafa \\
Supply chain & 1 main supplier \\
Food production methods & Organic, artisanal, and small scale \\
Ordering form & Excel sheet \\
Delivery form & Open order \\
Benefited consumers & 20 family units \\
Governance & Horizontal self management, with commission responsible for specific tasks \\
Legal entity & No legal entity \\
Producer-consumer interaction & Delivery days, visit to farmers, shared meals, educational and cultural \\
& activities, political activities \\
& Platform Per Russafa, Fundación CEDAT, Grupo a Grupo, La Plataforma per la \\
Network & Sobirania Alimentària \\
\hline
\end{tabular}

Just like Grupo de Consumo Vera, this group was born in the heat of $15 \mathrm{M}$, so the demands and concerns of the anti-austerity movement also triggered the creation of this collaborative food alliance. In July 2011, some people begin to gather at Platform Per Russafa, an association aimed at promoting the direct participation of the population in decisions affecting the neighborhood of Russafa. Among them, a group decided to start a consumption group for the people living nearby. It is considered by its members as not only a space of consumption but also a social and political space that allows them to abandon the capitalist logic of individualistic consumption.

About 20 family units benefit from the group. At Platform Per Russafa headquarters, the products are delivered every Wednesday, providing vegetables and fruits from a small farmer from the south rural area of the city (Figures 12 and 13). Occasionally, orders are made for products such as cereals, flour, meat, honey, sugar and oil. The products are all organic, not all are certified because the group understands that their personal relation with the producers is an important element in food quality, which may be more efficient than institutional stamps.

The governance system is strongly influenced by the $15 \mathrm{M}$, which the members call an "assembly" form of organization. It is a horizontal self-management dynamic, where commissions are set up for specific responsibilities such as ordering, distribution, internal and external communication, events, blog management and accountability. All decisions must be discussed and approved at group assemblies, so the active participation is required. Besides the commitment in participation in the Commission and deliveries, members contribute $€ 20$ when they join and $€ 1.00$ monthly for the group fund.

Talking about the advantages of supplying to this kind of initiative, Vicente, the main supplier, highlights the tolerance of people to deal with situations that are common in a small farm environment such as climate changes or droughts that may impact the quantity and quality of the vegetables, yet are not considered a problem for participants differently to what would happen if he were to sell to Mercadona, a local supermarket chain. Members, on the other hand, understand that the Group is also a way to fight for the survival of rural areas and family farmers, because the city was totally surrounded by farms, but since the 1960s the rural has been "destroyed" by the urban expansion and speculation, making it harder to have people working on the land. This is relevant for them because 
the social and environmental relevance those rural areas bring in terms of preserving local cultures and creating more ecologically sound environments.

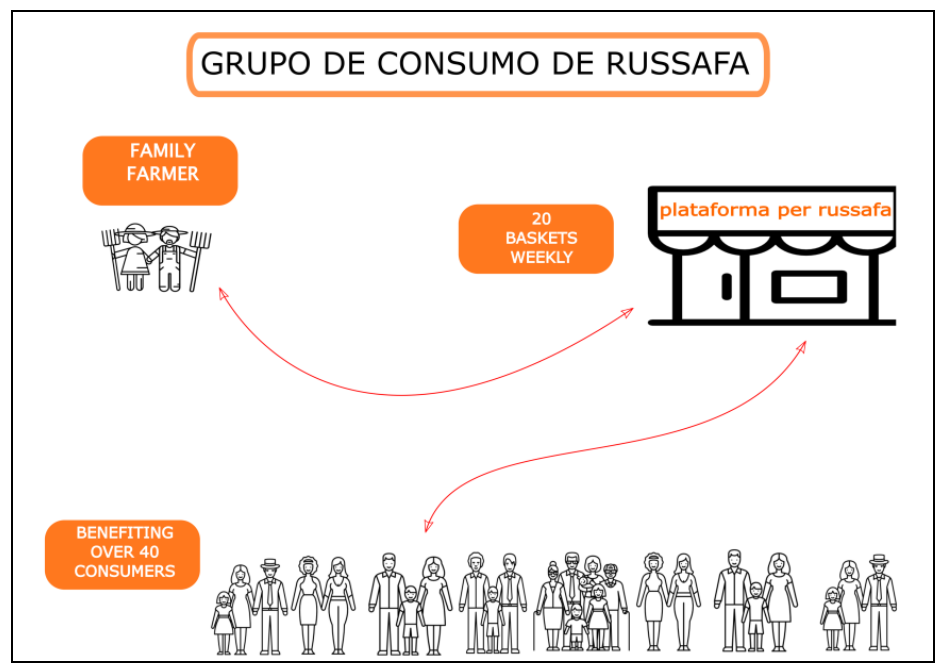

Figure 12. Supply chain dynamics of Grupo de Consumo de Russafa.

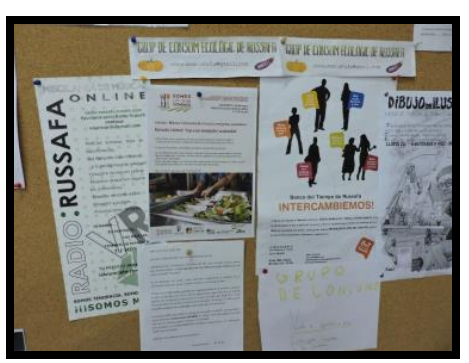

(a)

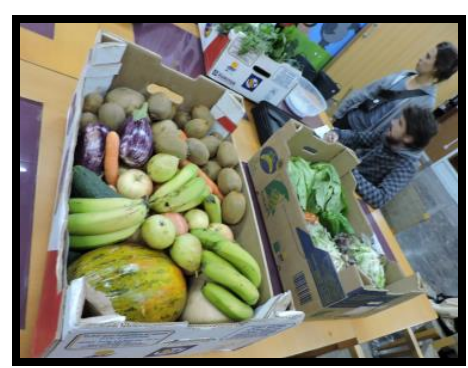

(b)

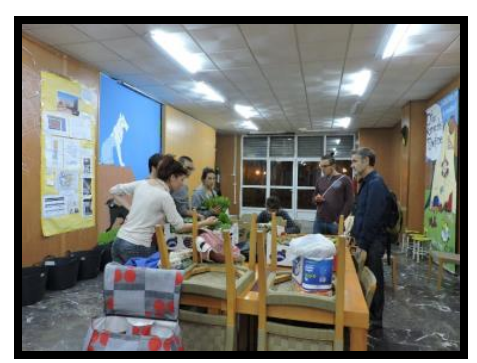

(c)

Figure 13. The board of activities from Platform Per Russafa (a); boxes with vegetables (b); and consumers socializing and sorting out their orders(c).

They organize cultural and social activities such as visits to organic farms, lectures and dinners. Most members of the Group have an active participation in the Platform Per Russafa, fighting for causes such as the preservation of environmental and heritage interest areas, improving the educational system and urban structure, promoting activities of social integration and socializing between neighbors. They are also engaged in the Grupo a Grupo and La Plataforma per la Sobirania Alimentària del País Valencià.

\subsection{De Groene Schuur (Zeist, Netherland)}

De Groene Schuur (The Green Barn) is located in Zeist, a small city in the Netherlands, about $50 \mathrm{~km}$ south of Amsterdam, Table 7 provides a synthesis of its heuristic analytical fields. It started by the initiative of Gabrielle; dedicated to raising her four children, she heard about the difficulty that Dutch farmers have selling their products to conventional markets during a holiday trip. The information came through a friend who was involved in a direct purchasing scheme called Groenteclub (Vegetable Club). It all started in 2012 with a young farmer throwing $5000 \mathrm{~kg}$ of potatoes in the Dam Square, a touristic place in the heart of Amsterdam historical center. The farmer was Krispijn van den Dries, involved in the Dutch Youth Food movement, who was acting to call people's attention to how the conventional food system pressures farmers in the Netherlands. In recent years, supermarkets have started to import vegetables from southern countries for very cheap prices, leaving Dutch farmers 
with their harvest and having to accept very low prices that may not even cover the production cost. Products travel many miles and obviously do not arrive fresh to consumers, in addition to creating a strong environmental impact in the process.

Table 7. Heuristic analytical fields from De Groene Schuur.

\begin{tabular}{cl}
\hline Heuristic Analytical Fields & \multicolumn{1}{c}{ De Groene Schuur } \\
\hline Localization & Zeist, Netherlands \\
\hline Origin & 2013, by the initiative of a consumer \\
\hline Supply chain & 1 main supplier (farmers collective-Bioromeo) \\
\hline Food production methods & Organic, bio-dynamic, artisanal \\
\hline Ordering form & Internet app \\
\hline Delivery form & Open order \\
\hline Consumers & 108 family units \\
\hline Governance & $\begin{array}{l}\text { There is a managing core group and other members collaborate for } \\
\text { assembling and delivering the food }\end{array}$ \\
\hline Legal entity & No legal entity \\
\hline Producer-consumer interaction & Delivery days, visit to farmers, shared meals \\
\hline Network & $\begin{array}{l}\text { There is some connection with other similar initiatives in the country } \\
\text { and Slow Food international }\end{array}$ \\
\hline
\end{tabular}

The action ended up getting a lot of media attention, and one of the articles reached Barbara Bolt, a middle-class woman resident of Bussum, a town in the province of North Holland. Touched by the situation, Barbara went to visit the Krispijn farm and soon began to persuade her neighbors to buy products directly from him. Over time, the initiative became the Groenteclub. Inspired by this experience Gabrielle decided, one year later, to initiate a similar experience, calling her neighbors and friends to join in. Thus, there were two main concerns that actors wanted to address, first to provide a stable markets for Dutch farmers, and second to have fresh ecological vegetables through closer social relations with producers.

Today, De Groene Schuur is composed by two groups, one with seventy family units that meets every Wednesday at Gabrielle's backyard to pick up their vegetables (Figure 14), and the other was a branch formed in 2015 that supplies 38 family units in the De Dieptetuin (In Depth Garden) area, a park on the other side of the city. The governance is composed by a core group of five that takes care of main managing tasks: ordering, liaison with producers and payments. All other members take turns to collaborate in the food assembling and delivering. Thus, on every delivery day a group of eight volunteers arrives at 8:00 a.m. to receive the products, unload the boxes and starts to separate each family order. The dynamic lasts until around 12:00 p.m., when all consumers arrive to pick up their boxes. They also pay a $20 \%$ fee on top of each purchase, to cover the cost of transport and small items necessary to the group's dynamic, such as bags, scales, coffee, etc. There is no legal entity registered.

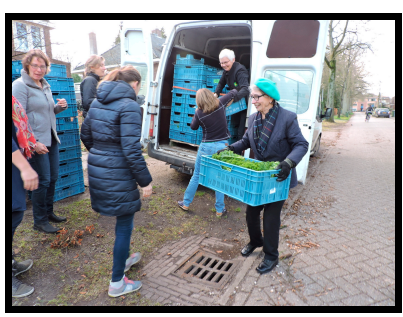

(a)

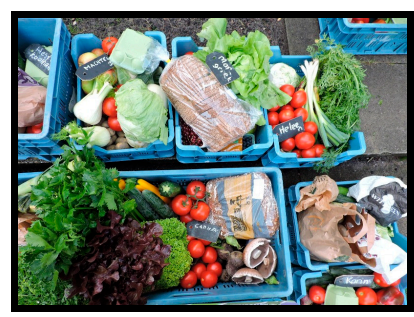

(b)

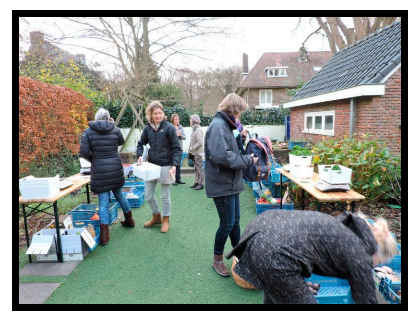

(c)

Figure 14. Consumers receiving products in the early morning (a); food boxes (b); and consumers organizing each other orders (c). 
Besides bread that comes from a local organic bakery, all other products come from a farmer's collective called BioRomeo (Figure 15). Basically, they are all Krispijn neighbors that cultivate organic and biodynamic fruits and vegetables in the Noordoostpolder area, Flevoland province, one hour drive from Zeist. With this cooperation they can each focus in producing specific varieties, something that besides facilitating their work avoids competition within community. Consumers benefit by receiving a wider range of certified organic products. This strategy has allowed them to currently supply another fifteen similar initiatives, which they call consumers co-operations.

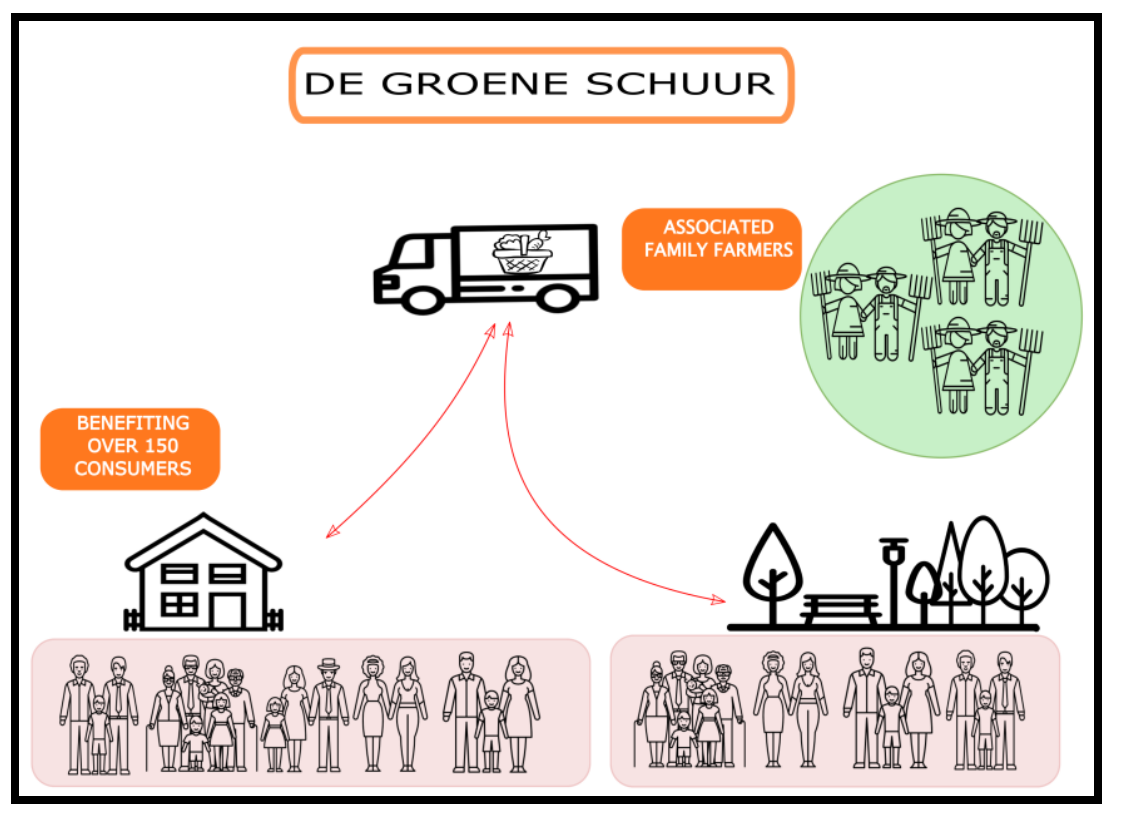

Figure 15. Supply chain dynamics of De Groene Schuur.

Besides delivery days, there are annual visits to farmers and some shared meals. Although the process of creation and functioning dynamics converge with the previous initiatives presented, in some ways, these Dutch experiences present some contrasts in relation to other experiences especially because most consumers do not perceive themselves as part of a political movement per se. The fact that the products are ecological is understood as essential not only for personal health issues, but is also interpreted as a contribution to the health of the planet. There is an appreciation of local varieties and the work done by the Dutch farmers, as well as a tendency to avoid shopping at big supermarkets. However, this is perceived as an individual support to things that they value. In the end, the outcomes sought by them are not exactly equivalent to those defended by the other initiatives presented

In addition, although farmers feel pressured and damaged by the conventional food system functioning just like other farmers involved with these initiatives in different countries, the context and the way of working of Dutch farmers is very different from all other analyzed experiences. In some ways we could consider Krispijn a family farmer, in the sense that he is the third generation farmer working on the family land. After World War II, the Dutch government began to distribute land in the Noordoostpolder region for those who were interested in working on the land. Krispijn's grandfather was one of the first to apply and to start his production. Years later, in the 1990s, his son-Digni-took over the work of the family and decided to convert the chemical based production into organic and biodynamic production. Later on, when Krispijn took over from his father, he decided to modernize production by machinery, which he considered a necessity in order to have a decent livelihood from the land. Thus, besides the use of tractors and harvesters, the vegetables processing-cleaning, separation by size and boxing-is done by machinery. Besides Krispijn and his father, there are about eight employees hired to work on the farm. In addition, the total area of fifty hectares considered normal 
for a small to medium producer in the Netherlands, is much larger than the farmers of the cases we have presented.

\section{Discussion}

The seven CFAs present different characteristics which compose complex and heterogeneous practices and discourses, but also many points of convergence, that we will try to address following the eleven heuristic fields that we have used to describe the cases. Sustainability is addressed in three dimensions: social (the reconnecting (rural) producers and (urban) consumers, personal trust relations, concern about quality of life and labor conditions and issues of social inclusion), economic (stable outlet for producers, fair price for producers) and ecological (the food production methods, food miles, low packaging use).

\subsection{Localization}

As far as location goes, we can see that CFAs are found both in big urban centers such as São Paulo and Rome, as well as in middle and smaller cities such as is the case of Riobamba and Zeist It is important to highlight that for all cases, the CFA intentionally build linkages between the urban and surrounding peri-urban and rural areas through the food supply, as a way to not only appreciate local products but also to cherish and sustain the people, the cultures and the environments.

\subsection{Origin}

In all initiatives, the first step is given by consumers, other than that, the origin of each case seems to be contingent, although affected by the location and the socio-political and economic circumstances surrounding the actors involved. The two Latin-American cases, Canasta Comunitaria Utopia and MICC, present interesting convergences in terms of time and circumstances, since they both appear in the mid-1980s when the countries were experiencing post-dictatorship periods, when economic crises were at play parallel to the blossoming of social movements. In addition, they were born under the strong influence of the Liberation Theology and involved since that time low-income populations in both the rural and urban areas, in their respective localities. The other cases started more recently, but even with different trajectories, they seek to consolidate a more socially inclusive and ecological type of food supply. In this sense, more recent events such as political and economic crises, immigration, and international food trade are elements that had a strong influence.

\subsection{Supply Chain}

Even though the supply chain is very specific to each case, they all contribute to establishing urban-rural linkages. All are forms of local supply, where the food comes from nearby rural areas within each city or in some cases from small business within the urban areas such as bakeries, breweries, or establishments producing flours, pastas, jellies, juices, wines and hygiene products. Economically, the resources invested in the purchase of such products end up feeding local economies and contributing to the reproduction of the actors involved.

Findings of Brunori et al. [23], when studying GAS, show benefits for both producers and consumers. By eliminating middlemen and several activities and materials (e.g., long periods of storage, packaging, labels, conservation techniques, among others) mutually beneficial economic solutions are created. The findings of the cases presented and discussed in this article corroborate with these results.

In ecological terms, the proximity of the supply chain means that products travel a short distance between production and consumption, less than $100 \mathrm{~km}$ in all cases. In social terms, the preference for local products, delivered by artisanal and small scale producers not only creates a marketing channel for producers, but also valorizes, protects and preserves local knowledge, food cultures and biodiversity, as also indicated by Fonte [24]. However, it is important to consider that shortening the spatial and social distance between producers and consumers by establishing direct interactions 
does not guarantee sustainability and lower environmental pressure. As Brunori et al [25] argue localized food systems and short food supply chains should not a priori be equated with sustainable food systems. Nonetheless, in all cases, local production and thereby avoiding food miles is an important criterion from an ecological impact point of view. Furthermore, all fresh vegetables and fruits are delivered in boxes that avoid the use of unnecessary packaging or plastic bags. Insofar as the empirical evidence from the studied initiatives demonstrates, we believe that they are all credible and valuable attempts and strategies to achieve sustainability in terms of a more equitable (and maybe resilient) relationship between economic, social and environmental dimensions of food production and consumption.

\subsection{Food Production Methods}

The forms of production are mostly based on methods of low external inputs such as organic, agroecological, or biodynamic farming. Canasta Comunitaria Utopía is the only one that also buys conventional products, in particular from the Mercado Mayorista, but over the years it has increased the share of agroecological products. It is also important to consider that ecological production for some is a process that involves learning and a change of practices of the farmers, which does not happen overnight. In this sense, it is important to mention that Canasta had and still has an essential role in contributing to the agroecological transition process of local farmers, especially in the case of the Indigenous Communities of Tzimbuto and Basquitay. This process is partly presented by Soto [26] who followed the first encounters between the farmers in the community and the consumers from Canasta Comunitaria Utopía.

\subsection{Ordering Form}

The ordering form is a reflection of the kind of technology that actors have access to. All European initiatives work with some kind of online ordering system, meaning that farmers, producers and consumers must not only have access to this technology but also the knowledge and skill to manage it. This challenge has also been addressed by Brunori, Rossi, and Malandrin [27] who argue that to be able to deliver food to a GAS farmers may experience difficulties or limitations or will at least need to develop knowledge and skills beyond food production and marketing, such as the use of online product ordering systems. It is interesting to see that the two Latin-American experiences once more converge since they organize ordering through face-to-face interactions or phone calls. Although Internet use is common in both countries, and the core groups managing Canasta Comunitaria Utopia and MICC both believe that changing to online ordering could be more practical, they have decided not to implement it as it would likely restrict the participation of both consumers and farmers that at the moment do not have access to those technologies.

\subsection{Delivery Form}

The delivery form has an impact on social relations as in all alliances consumers take turns in assembling and delivering the food. This is not just a means to save costs. For most consumers it is a pleasant task that allows them to socialize with each other and with farmers, leading actors to refer to delivery days as "being at a party or going to the bar with friends" Delivery days are usually a moment where consumers can get feedback from farmers about their work and the possible problems that they had during harvesting. More than justifying why the order may not be exactly what consumers expected, this keeps the consumers tuned to the situation that farmers are experiencing, becoming a space for dialogue for the everyday life experiences in both sites, urban and rural.

The way food is delivered, in closed baskets or open order, may be an interesting aspect to reflect on, because this practice provides a clue about to what extent people are open to new experiences. In the case of closed basket it is necessary to be willing to accept that someone else chooses the food for you. In that sense a very common statement among consumers in the closed basket initiatives is that they end up getting in touch with food they had not known before or were not used to consume. 
Although with greater freedom of choice, consumers of initiatives with open order also report similar situations. These aspects connect to the study of Carolan [28] who analyses CSA claiming that after engaging in such initiatives, consumers experience change in diets and need to learn how to handle and eat different food. Thus, these initiatives encourage people to have more diverse diets. This is relevant not only in terms of personal health but also a key issue for maintaining biodiversity as a key element for more resilient ecosystems [29]. Millestone and Lang [30] estimate that only 10 percent of the variety of crops that used to be available in the past are still being produced by farmers. By developing new food habits, consumers help to foster farmer's practices of growing different varieties. Thus, through the foods that they eat consumers have the potential to affect the agrobiodiversity in rural areas.

\subsection{Consumers}

From the point view of gender, age and professional background, we find a large variety among the cases making it impossible to create a uniform profile of consumers. Considering the income level, it is generally assumed that actors involved in the direct purchasing of environmentally sound products are limited to more affluent classes. Two studies shed a somewhat different light on this assumption. One study was carried out in five different cities in Brazil where the prices of 22 products were compared for four different outlets: supermarket, conventional farmers market, organic farmers market and Responsible Consumer Groups, among them MICC [31]. The study concluded that for organic products, the short circuits-farmer's market and consumer groups tend to have lower prices compared to supermarkets and the conventional farmer's market. While a basket with seventeen organic products cost US $\$ 44.00$ at the supermarket, the same set of products could be obtained through a CFA for US\$21.00, so less than half the supermarket price. The study also revealed that organic products shopped at supermarkets could be up to four times more expensive than those provided by a CFA. The second study, carried out in Rome by Crisci [32], who compared eight marketing channels: GAS Testaccio Meticcio, two supermarkets, two specialized organic shops, a discount market and two other local markets. GAS prices were lower for most categories of organic products in relation to other supply chains and when comparing with the average prices of conventional products, only the discount market had really lower prices. For all other channels, the average prices were higher or similar to those found in GAS. Prices of products like pasta, flour, vegetables, fruits, honey and tomato sauce were $15-23 \%$ lower when purchased through a GAS.

These data confirm the claims made by actors involved in the CFAs that they offer more economic prices for consumers as well as higher payments for farmers. Even when food products provided through CFAs are not cheaper, they are at least competitive to those provided by conventional marketing channels. This opens the ground to question the idea that organic food is more expensive and therefore restricted to an elite or niche markets, indicating that perhaps it is not the production method, but the marketing channel that results in higher prices. In addition, it is important to take into consideration that even though products are free of pesticides, not all are organically certified. As the type of certification has an influence on final prices, CFA farmers tend to either use participatory certification systems or dismiss certification completely, understanding that the personal relation established with consumers is sufficient.

\subsection{Governance}

The governance arrangement is influenced by the size of the group. CFAs with a large number of consumers and suppliers end up having some kind of core management group. Such a management group is lacking in smaller CFAs as the Italian and Spanish cases. Despite the number of participants, they all have a strong degree of participation. In particular, the aforementioned need for consumers to take turns in assembling and delivering the food, gives them an opportunity to interact with farmers and get first-hand information about possible food delivery problems caused by for instance drought, frost or outbreak of a disease. 
Another element is that for both producers and consumers to engage in CFAs there is a need to develop skills to manage software, to liaise with partners, and to handle food and finances. This means that consumers who just want to "buy food" may have a hard time to participate in a CFA.

\subsection{Legal Entity}

The issue of legal registration refers to the questions of whether and how formalization of CFAs is a means to maintain their activities, especially with regard to the ability to make larger purchases for which receipts are necessary. In this sense, the Italian initiatives have a great prominence because they are the only ones with the possibility of registering really as a GAS, something that the consumers of the Consumption Group Vera are still trying to realize.

Most of the groups operate in a more informal atmosphere and even when legally registered it is more connected to some kind of non-profit community association. This may indicate the difficulty of legally creating and recognizing alliances dedicated to food supply that differ from already existing ones. A more in-depth study on this aspect could explore the need for formalization and the way in which this influences the dynamics of and possibilities and constraints for CFAs.

\subsection{Producer-Consumer Interaction}

The delivery days combined with other spaces where producer-consumer interact, strongly contributes to the strengthening of urban-rural links as it allows consumers to know what is happening to producers and how it affects their produce. Visits to farmers play a key role in this case, not only because friendships are established but also because consumers have the opportunity to see firsthand farmers' life world, and to understand the conditions in which they live and work. In this sense, it is important to note how all groups converge around the concern to support producers that are, to a certain degree, vulnerable, rather than collaborating with producers because they are small or organic. The different cases show that "solidarity" is more than a shared value, it is becoming a practice.

This practice of solidarity has also been addressed by Kneafsey and colleagues [33], who argue that these relationships are crossed by an "ethics of care" in which feelings of empathy, affection and care create a constructive relationship in search for the consolidation of longings like knowing who produces their food or who buys their products. This explains why all initiatives promote so many spaces of socialization that, sometimes, seem to be as important as, or even more relevant than, the food that circulates, causing consumers to refer to social relations at the top of their motivations to be engaged in a CFA.

\subsection{Network}

Finally, considering the networks in which the CFAs are embedded, it is interesting to see that there is no mentioning of state or other kind of governmental support at all. Social movements and NGOs are the most frequent and present in all initiatives, mostly those who now work with rural development, peasants and agriculture. Therefore, it is undeniable that there is also a political practice in CFAs, which is expressed in the way most CFAs started. This is also placed at the top of the motivations in many of the cases. The type of social movement with which a CFA has a relationship affects its identity and practices, for example: the large number of MICC delivery points associated with churches or religious centers, can be considered a mark of its connection with the Liberation Theology Movement; the "assembly" form of organization that the Spanish cases Inherited from the 15M; or the practice of Italians in associating the purchase of food with dinners, a characteristic practice of the Slow Food movement, which defends and disseminates values and practices linked to commensality.

De Groene Schuur is the only initiative that is involved in advocacy politics as one of its goals or practices. However, the emergence of De Groene Schuur is a direct result of a political action by Krispijn, the farmer who belongs to the Dutch Youth Food Movement. Krispijn as well as some of the consumers involved do understand that consumption is a political act. In addition, it is important 
to highlight that the social and environmental concerns expressed by the other CFAs as mobilizers for political actions, are also mentioned by De Groene Schuur participants. However, not everyone understands this to be associated with a political engagement; some believe it is a contribution that they make as individuals to the creation of the kind of society they believe. In the end, it seems to us that it is much more a question of what is meant by politics, which in the latter case is associated with more institutionalized forms such as participation in elections.

Another aspect to consider is that those alliances involve more than organizations and movements, but also people, places, materialities and subjectivities that ultimately are expressed and imprinted in the food that circulates. In this sense we can use the example of the process of choosing a new supplier from the Grupo de Consumo Vera where consumers eat in a circle and together taste the products or for instance the early actions of MICC purchasing entire harvest from MST as a way to materialize political support. Thus, through the alliances a kind of food supply materializes in which there is a strongly shared understanding that consumption has a political significance. Following Micheletti [34] we can perceive that this challenges traditional thinking about politics as something centered on a system of a nation-State. Even more, it may challenge the understanding of what it means to have political participation in society or what the connections are between politics and economics. CFAs are political, as stated by Sherwood et al. [35], as actors seek to incorporate practices they feel are more consistent with their own rationales and agendas, renouncing the passive role of just absorbing and following the mainstream food.

This political character reinforces our argument that these CFA cannot be seen as mere food markets or niches. The way the relationships are established and the social and political practices that are maintained go far beyond a mercantile process. Thus, there is an understanding that by associating with certain farmers and producers, consumers are supporting certain social groups, as well as the economic and environmental practices that are relevant to them. This is exactly what the Italian participant's claim as "to do politics without parties". Although there is no clear association with or support from the state for the creation and maintenance of CFAs, in the case of Canasta Comunitaria Utopia there was an inverse process of it having a prominent role in the creation of the laws on pesticide use and agroecological production that make up the current Constitution of Ecuador. As previously addressed, GAS have a legal recognition within the country legislation as a kind of food supply. With their participation in the Rede Escola e Cidadania (School and Citizenship Network), MICC plays an important role influencing the political outcomes and the attention of the state for communitarian demands at São Paulo's east side.

\subsection{Significance of $C F A s$}

Usually, there is a high interest in understanding the economic significance at national level of such forms of supply or in understanding their potential to transform the dominant food system. However, this was not the objective of this study and therefore questions along these lines cannot be answered. Nonetheless, two issues related to potential economic significance can be addressed. First, is to ask what kind of economic significance we should be looking for. Is it how something is translated into the country's Gross domestic product (GDP) or how something is translated in economic return for people's life? If we consider the first, the contribution of the CFAs would be probably insignificant, especially if we consider a single case. If we considered that there are 900 GAS in Italy and certainly thousands of farmers having their income from them, maybe we could see some impact at national level.

However, what we can conclude is that the income generated by producers involved in these CFAs is quite significant for the families involved, in some cases is their main income source (MICC and Canasta Comunitária Utopia), also for specific producers in the Italian cases such as Barikamà and La Nuova Arca. For others is an important complementary income, as is the case for other GAS suppliers, the two Spanish groups and the De Groene Schuur. Secondly, even though they do not have economic significance for the country, they are extremely important for small producers as they serve as a 
starting point for other forms of marketing, helping then to improve their organizational processes and allowing them to expand their markets. This is clearly the case of MICC, Canasta, the two Spanish groups, De Groene Schuur and many producers for the Italian cases.

With the exception of Ecuador, in all other countries the number of CFAs as well as other kinds of local food systems is increasing, with more initiatives every year. CFAs have a critical stance towards the mainstream food supply. This is not expressed through a direct confrontation but rather by avoiding mainstream markets and foods and by materializing different kinds of socio-economic relations, foods, environments, practices and values. Therefore, we believe that the most relevant contribution that CFAs bring is not expressed by their economic significance for their respective countries or by their ability to radically transform the mainstream food supply. It is a more subtle and subjective contribution that affects people's everyday life, contributing to processes of social change, political engagement, food security and sovereignty, as well as by supporting critical reflections on agriculture, food and consumption practices.

\section{Conclusions}

The aim of this article was to present a transnational analysis of how a specific kind of direct food supply, Collaborative Food Alliances, may help to foster sustainable urban-rural linkages. We drew our findings from seven different cases, located in five different countries, by using eleven heuristic analytical fields to present the initiatives and discuss the results in the light of literature.

Many elements of convergence were found among the initiatives that through the alliance of consumers and producers contribute to strengthen urban-rural linkages and foster a local food supply considering at least three dimensions of sustainability: social, ecological and economics. City dwellers are benefited by receiving organic products on a stable basis and at a fair price, as farmers manage to structure a consistent market with good incomes, while establishing social ties that are comprehensive and tolerant to the difficulties of small production. Furthermore, we argue that CFAs must be recognized as more than a simple form of marketing or food supply due to the characteristics and practices it fosters, in which socialization activities, political action and collective learning processes are an essential part of its identity.

By establishing specific food schemes, these initiatives are not only questioning the mainstream food supply, but are materializing new markets and social relations, reconfiguring the role of consumers and producers and enabling transformative alliances for their realities as well as fostering sustainable urban-rural linkages.

Acknowledgments: The authors gratefully acknowledge the relevant contributions from Alberto Arce, from Wageningen University, that helped to improve the paper. In addition, we thank two anonymous reviewers for their valuable comments and questions.

Author Contributions: Potira Preiss has carried out the fieldwork, analyzed the data and designed the paper. Potira Preiss, Flávia Charão Marques and Johannes S.C. Wiskerke have collaboratively written the manuscript.

Conflicts of Interest: The authors declare no conflict of interest.

\section{References}

1. Food and Agriculture Organization of the United Nations (FAO). The Future of Food and Agriculture: Trends and Challenges; FAO: Rome, Italy, 2017.

2. Van der Ploeg, J.D. Sete Teses Sobre a Agricultura Camponesa. Available online: https://www. researchgate.net/publication/283451041_Sete_teses_sobre_a_agricultura_camponesa (accessed on 2 July 2017). (In Portuguese)

3. Renting, H.; Marsden, T.K.; Banks, J. Understanding alternative food networks: Exploring the role of short food supply chains in rural development. Environ. Plan. 2003, 35, 393-411. [CrossRef]

4. Popkin, B.M.; Adair, L.S.; Ng, S.W. NOW AND THEN: The Global Nutrition Transition: The Pandemic of Obesity in Developing Countries. Nutr. Rev. 2012, 70, 3-21. [CrossRef] [PubMed] 
5. Mélard, F.; Mormont, M. The Pragmatic Collective Interest as the Product of Civic Deliberation: The Case of Pesticide Management in Belgium. Sustainability 2013, 5, 2233-2251. [CrossRef]

6. Cecchini, M.; Sassi, F.; Lauer, J.A.; Lee, Y.Y.; Guajardo-Barron, V.; Chisholm, D. Tackling of unhealthy diets, physical inactivity, and obesity: Health effects and cost-effectiveness. Lancet 2010, 376, 1775-1784. [CrossRef]

7. Fonte, M. Knowledge, food and place: A way of producing, a way of knowing. Sociol. Rural. 2008, 48, 200-222. [CrossRef]

8. Goodman, D. Rural Europe redux? Reflections on alternative agro-food networks and paradigm change. Sociol. Rural. 2004, 44, 3-16. [CrossRef]

9. Holt-Giménez, E.; Shattuck, A. Food crises, food regimes and food movements: Rumblings of reform or tides of transformation? J. Peasant Stud. 2011, 38, 109-144. [CrossRef] [PubMed]

10. Renting, H.; Schermer, M.; Rossi, A. Building Food Democracy: Exploring Civic Food Networks and Newly Emerging Forms of Food Citizenship. Int. J. Sociol. Agric. Food 2012, 19, $289-307$.

11. Sonnino, R.; Marsden, T. Beyond the divide: Rethinking relationships between alternative and conventional food networks in Europe. J. Econ. Geogr. 2006, 6, 181-199. [CrossRef]

12. Picolotto, E. Novos movimentos sociais: Economia solidária e comércio justo. Rev. Otra Econ. 2008, 2, 74-92.

13. Star, A. Local Food: A Social Movement? Cult. Stud. Crit. Methodol. 2010, 10, 479-490. [CrossRef]

14. Lamine, C. Settling Shared Uncertainties: Local Partnerships Between Producers and Consumers. Sociol. Rural. 2005, 45, 324-345. [CrossRef]

15. Rete Nazionale Dei Gruppi Di Acquisto Solidale. Available online: http:/ /www.retegas.org (accessed on 10 April 2017).

16. Kirwan, E. La canasta comunitaria: Una plataforma urbano-rural para la seguridad alimentaria. Rev. Agroecol. 2008, 3, 26-29. (In Spanish)

17. Marcus, G.E. Ethnography in/of the world system: The emergence of multi-sited ethnography. Annu. Rev. Anthropol. 1995, 24, 95-117. [CrossRef]

18. Falzon, M. Multi-Sited Ethnography: Theory, Praxis and Locality in Contemporary Research; Ashgate Publishing: Surrey, UK, 2009.

19. Vossoughi, S.; Gutiérrez, K. Studying movement, hybridity, and change: Toward a multi-sited sensibility for research on learning across contexts and borders. Natl. Soc. Study Educ. 2014, 113, 603-632.

20. Blanco, G.; Arce, A.; Fisher, E. Becoming a region, becoming global, becoming imperceptible: Territorialising salmon in Chilean Patagonia. J. Rural Stud. 2015, 42, 179-190. [CrossRef]

21. Holloway, L.; Kneafsey, M.; Venn, L.; Cox, R.; Dowler, E.; Tuomainen, H. Possible food economies: A methodological framework for exploring food production-consumption relationships. Sociol. Rural. 2007, 47, 1-19. [CrossRef]

22. Fonte, M. Food consumption as social practice: Solidarity Purchasing Groups in Rome, Italy. J. Rural Stud. 2013, 32, 230-239. [CrossRef]

23. Brunori, G.; Rossi, A.; Malandrin, V. Co-producing Transition: Innovation Processes in Farms Adhering to Solidarity-based Purchase Groups (GAS) in Tuscany, Italy. Int. J. Sociol. Agric. Food 2010, 18, $28-53$.

24. Fonte, M. Food relocalisation and knowledge: Dynamics for sustainability in rural areas. In Naming Food after Places: Food Relocalisation and Knowledge Dynamics in Rural Development; Fonte, M., Papadopoulos, A.G., Eds.; Ashgate: Farnham, UK, 2010; pp. 1-35.

25. Brunori, G.; Galli, F.; Barjolle, D.; van Broekhuizen, R.; Colombo, L.; Giampietro, M.; Kirwan, J.; Lang, T.; Mathijs, E.; Maye, D.; et al. Are Local Food Chains More Sustainable than Global Food Chains? Considerations for Assessment. Sustainability 2016, 8, 449. [CrossRef]

26. Soto, M. La Ciudad Visita al Campo. Redefining the Relationship between Producers and Consumers in the Ecuadorian Andes EkoRural, Internship Report; College of the Atlantic: Bar Harbor, ME, USA, 2010.

27. Brunori, G.; Rossi, A.; Guidi, F. On the new social relations around and beyond food. Analysing consumers' role and action in gruppi di acquistosolidale (solidarity purchasing groups). Sociol. Rural. 2012, 52, 1-30. [CrossRef]

28. Carolan, M.S. Embodied Food Politics; Ashgate Publishing: Farnham, UK, 2011.

29. Smith, J.; Lang, T.; Vorley, B.; Barling, D. Addressing Policy Challenges for More Sustainable Local-Global Food Chains: Policy Frameworks and Possible Food "Futures". Sustainability 2016, 8, 299. [CrossRef]

30. Millstone, E.; Lang, T. The Atlas of Food: Who Eats What, Where, and Why; Earthscan: London, UK, 2008. 
31. Instituto Kairos. Alimentos Sem Veneno São Sempre Mais Caros? Available online: http:/ /institutokairos. net/2016/04/alimentos-sem-veneno-sao-sempre-mais-caros / (accessed on 10 April 2017). (In Portuguese)

32. Crisci, G.; Fonte, M. L'accesso al bio nellatransizione verso la sostenibilitàdeisistemi agro-Alimentari. Agriregionieuropa 2014, 37, 2-7. (In Italian)

33. Kneafsey, M.; Cox, R.; Holloway, L.; Dowler, E.; Venn, L.; Tuomainen, H. Reconnecting Consumers, Producers and Food: Exploring Alternatives; Berg: Oxford, UK, 2008.

34. Micheletti, M. Political Virtue and Shopping: Individuals, Consumerism, and Collective Action; Palgrave: New York, NY, USA, 2003.

35. Sherwood, S.; Arce, A.; Berti, P.; Borja, R.; Oyarzun, P.; Bekkering, E. Tackling the new materialities: Modern food and counter-movements in Ecuador. Food Policy 2013, 41, 1-10. [CrossRef]

(c) 2017 by the authors. Licensee MDPI, Basel, Switzerland. This article is an open access article distributed under the terms and conditions of the Creative Commons Attribution (CC BY) license (http:// creativecommons.org/licenses/by/4.0/). 